Historic, archived document

Do not assume content reflects current scientific knowledge, policies, or practices. 

a 3511

United States

Department

Forest Service

Alaska Region

Report

\section{The Forest Service \\ in Alaska}
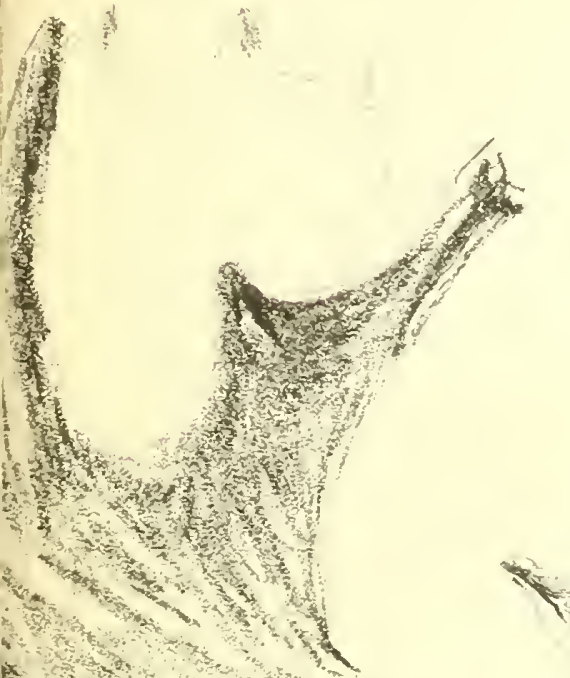

$x \rightarrow-1$,

1.1. Mn

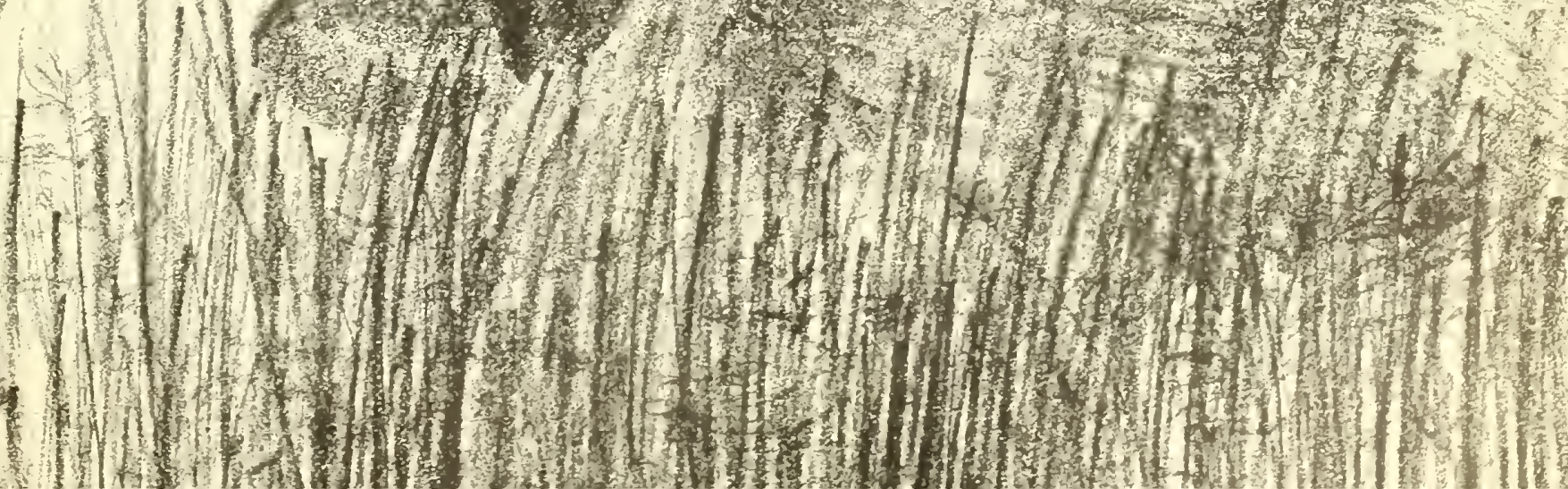


Page Contents

3 Introduction

5 Cooperative Forestry

5 Landownership

5 State and private forestry programs

7 Land Management Planning

7 Area guides

7 Forest land management plans

7 Roadless area review and evaluation

7 Interdisciplinary teams

7 Socioeconomic studies

8 Forest Research in Alaska: Past, Present, and Future

8 Research at Juneau

9 Research at Fairbanks

10 Recreation

10

10

12

13

14

Recreation

Recreational use patterns

Wilderness and other special classifications

Cultural resources

Visual resources

Fisheries and Wildlife

14 Surveys and studies

14 Effects of timber harvesting

15 Habitat improvements

15 Land allocations

15 Cooperation with other agencies

16 Stream management

16 Threatened and endangered species

16 Aquaculture

17 Timber Management

17 Reforestation and sale area improvement programs

17 Stream protection

17 Timber sale administration

17 Long-term and independent timber sale programs

17 Allowable timber harvest levels

20 Soils and Water

20 Land Uses

21 Minerals

22 Transportation System

24 Human Resource Program

24 Youth Conservation Corps

24 Young Adult Conservation Corps

25 Other human resource programs

25 Equal opportunity

28 Education

28 Information Services

29 Administrative Support

30 Key Forest Service Personnel 


\section{4 \\ The Forest Service in Alaska \\ Regional Fonester John A. Sandor and Others}

\section{Introduction}

Many people express continued concern for the conflicts that may exist between developmental activities on the national forests in Alaska-mainly timber harvesting, roadbuilding, and mining - and other important resource values, such as fisheries, wildlife, scenic values, and wilderness. The Forest Service recognizes the potential for conflict and shares these concerns. The challenge of multiple- use management is to develop techniques for minimizing or resolving conflicts between a variety of uses so the public may enjoy the greatest overall benefits from the national forests.

At the same time, many significant activities have been undertaken and merit attention, even though they may not have been controversial. It is also worthwhile to look at these activities so that positive aspects may be preserved and the problem areas corrected.

The emphases on the Resuurces Planning Act and land management planning have been designed to create close cooperation between local, State, and Federal Governments and all concerned segments of the public. Completing the "Tongass Land Managment Plan," for example, was certainly an important step toward resolving some conflicts and being more responsive to the people of southeast Alaska. Detailed land management planning is ongoing on the Chugach National Forest, and it likewise demands the participation of all segments of the public and Government.

Good plans are valuable only when they are implemented on the ground, and staffing has been substantially increased for both the planning and administration of timber harvesting and roadbuilding activities. As a result, major changes in on-theground practices have taken place in recent years. Examples include cuttingunit size limitations, restrictions on logging steep slopes, and guides for stream protection. An interdisciplinary team (IDT) approach is used to guide the project work and implement new require ments. All on-the-ground activities of a potentially sensitive nature are under. taken within the constraints of guidelines and recommendations developed by IDTs. The IDT process is defined in detail in the "Southeast Alaska Area Cuide" and training sessions have been conducted throughout the region.

In Alaska, as is the case nationwide, a critical issue is the amount of wilderness
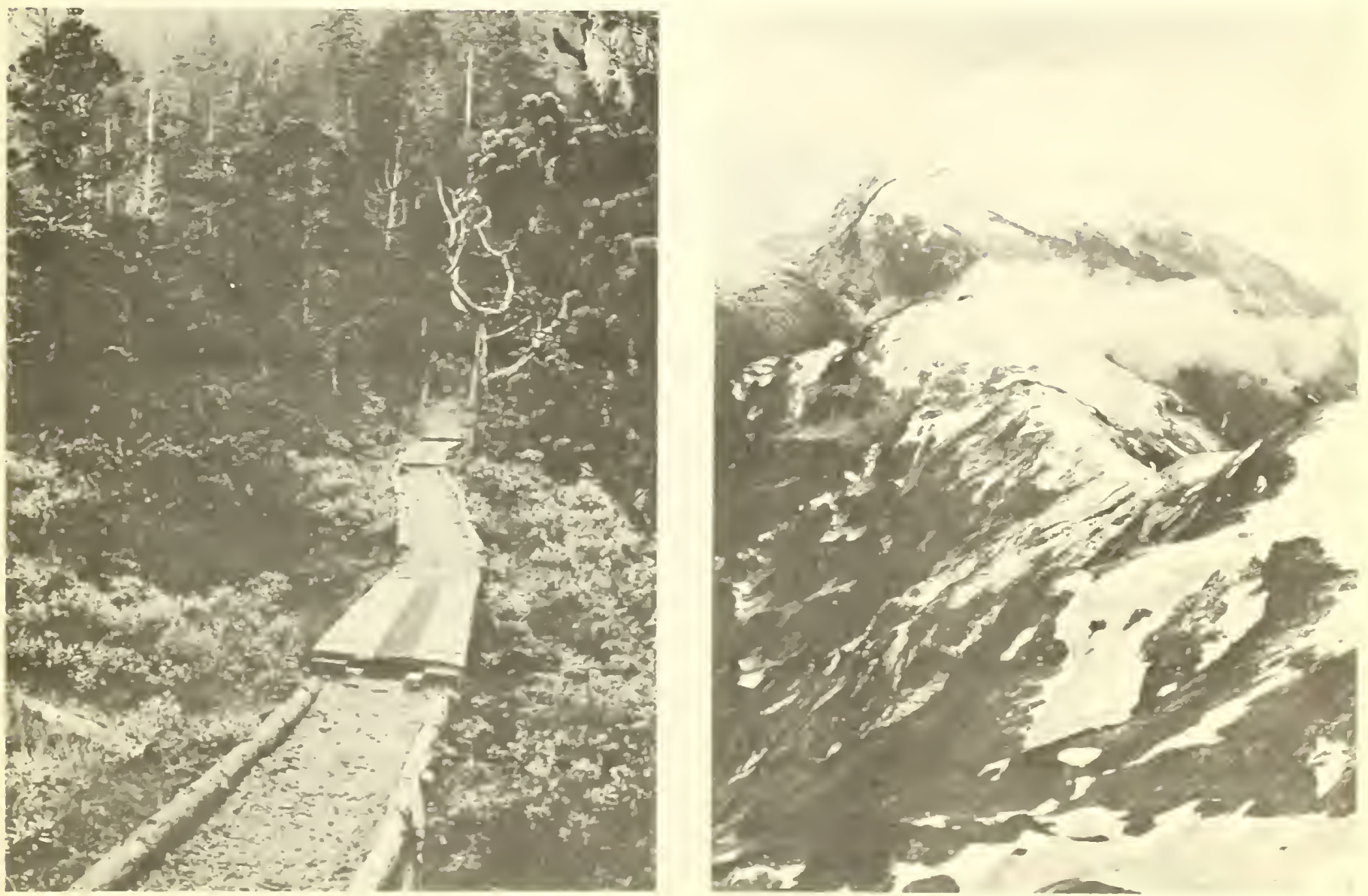
the national forest lands should provide. Through the land management planning process, the Alaska Region has developed alternative recommendations for allocating lands to immediate wilderness, wilderness study, special management areas, or to multiple-use management other than as wilderness.

The Alaska Region is placing major emphasis on providing employment opportunities through the Youth Conservation Corps (YCC). About 150 Alaskan youths are employed under the YCC program, and 410 young people work in the Young Adult Conservation Corps (YACC). Activities under these programs provide needed conservation improvements as well as training and jobs for young adults.

The Alaska Native Claims Settlement Act (ANCSA) and the Alaska Statehood Act are effecting a major shift in landownerhip patterns in Alaska from Federal to State and private ownership. This shift is still taking place. But, one result has been the rapidly expanding role of the Forest Service and the State Forester's office in providing technical forest land management assistance to the new private landowners, mainly the Native corporations.

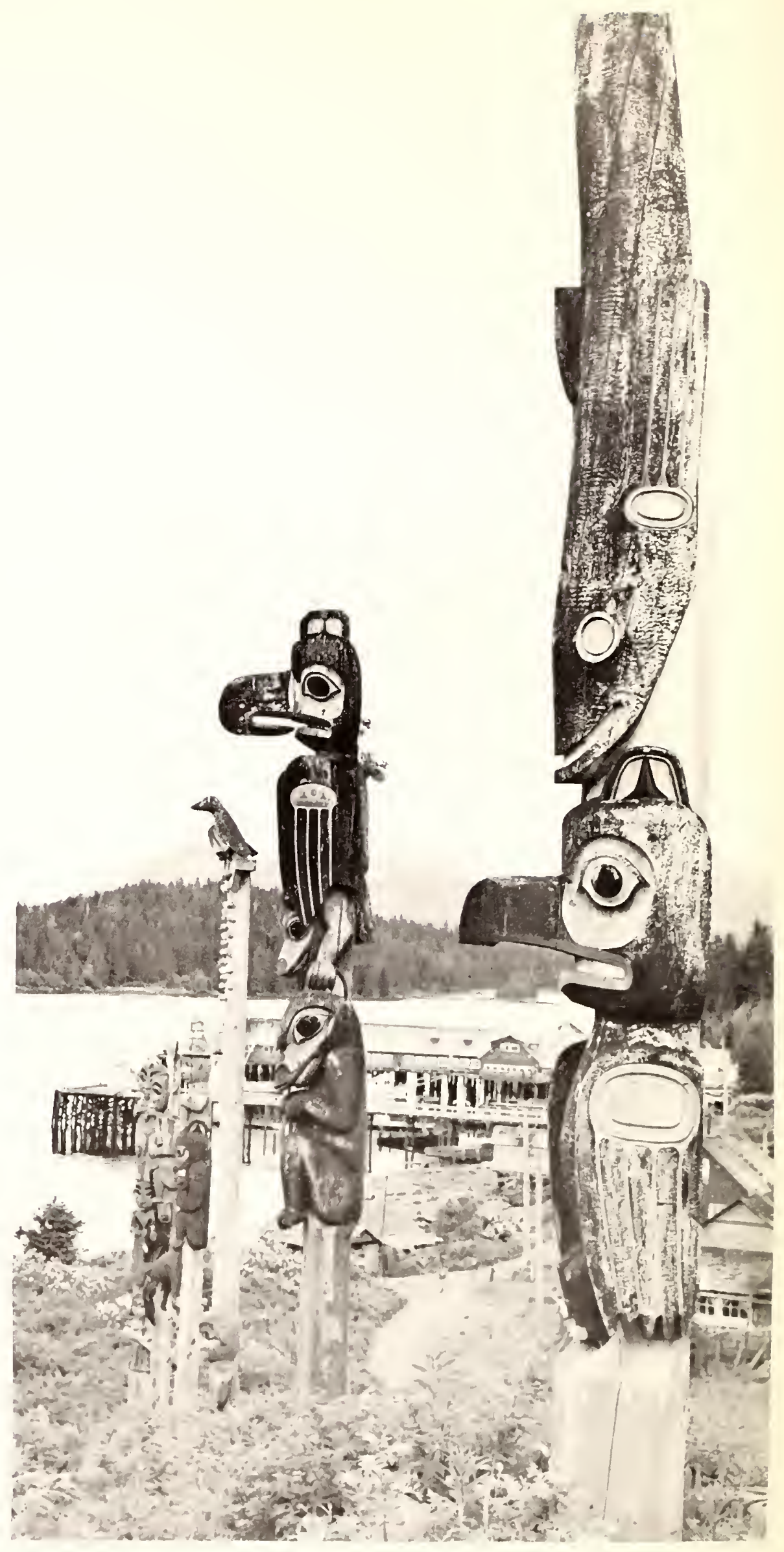




\section{Cooperative Forestry}

\section{Landownership}

Landownership patterns for Alaska, including the national forests in Region 10 , are undergoing monumental change. At the time of statehood late in the fifties, more than 90 percent of Alaska land was under Federal ownership. Significant changes have taken place since that time. ANCSA provided that more than 40 million acres of Federal land in Alaska would be conveyed in fee title to Native corporations. The Alaska Statehood Act of 1958 set aside 104 million acres of Federal land for selection by the State before 1984 .

Alaska's land base is 365 million acres. Implementing the Alaska Statehood Act and ANCSA will establish 104 million acres under State ownership and 44 million acres under private ownership. More than 140 million acres in Alaska are classified as forested land. Of this, the State has already selected 28 million acres, and Native lands are expected to include more than 17 million acres of forested lands.

In coming years, ANCSA will bring about landownership changes through Native land selections and ANCSA's Section $17(d)(2)$ land designations, in addition to State of Alaska land selections. These changes will significantly affect national forest management in Alaska for many years. This demands good land adjustment planning and implementation.

Native selections alone will remove nearly a million acres from national forest lands. Very high resource values in recreation, wildlife, and timber will be affected. The Forest Service (FS) will be working with the Native corporations, the State, Bureau of Land Management (BLM), and others on land adjustment proposals.

Each Native village on the Chugach National Forest will select 69,120 acres of land. In addition to villages named in ANCSA, the City of Kodiak will also select one township, 23,040 acres, from the national forest. Also subject to selection by Alaska Natives are Native historical sites, cemeteries, and certain individual residence sites. If all corporations on the Chugach are determined to be eligible under the ANCSA, about 454,000 acres of the Chugach National Forest would be conveyed to Native ownership.

Each Native village on the Tongass National Forest will receive 23,040 acres of national forest land. Sitka and Juneau urban Native corporations each will also receive 23,040 acres. Sealaska, the southeast Alaska regional corporation, is eligible to select an estimated 279,000 acres from the national forest. These selections, along with selections for historical sites, cemeteries, and small isolated Native groups, will remove an estimated 525,000 acres from the Tongass.

The period between passage of the act and final conveyance of selected land is a challenging one to both the Native corporations and the Forest Service. Although ANCSA provides the authority for continued management of the national forests by the Forest Service before conveyance to the Natives, it also provides for "maximum participation by the Natives in decisions affecting their rights and property." The corporations, in their efforts to protect the present and future interest of their stockholders, can legitimately question past management decisions made by the Forest Service and current efforts to fulfill contractual obligations.

Certainly, problems will continue to arise until land title conveyances are complete. Thus, we are committed to support and assist Native corporations in their land claims and to encourage conveyances as rapidly as possible.

\section{State and Private Forestry Programs}

The regional and village Native corporations authorized by the ANCSA are struggling with a variety of social, economic, and cultural decisions that must be made. Many of these decisions directly relate to management of the resources on or under their newly acquired lands. Ten regional corporatıons and 130 village corporations will possess renewable forest land resources of high value.

Much of the most valuable timber land to be acquired by Native corporations lies within the Tongass National Forest. The annual timber harvest from these lands could offer an economic development opportunity to overcome critical unemployment problems now prevalent in many rural communities. Forest Service and State assistance will be a positive factor in developing these and other opportunities throughout Alaska.

During this critical transition period, the Native corporations should be given adequate technical assistance in forest land management. The expertise and responsibility lies with the Alaska State Forester and with the Forest Service through its State and Private Forestry Program. This program now provides assistance to many of the Native cor. porations.

Forest insect and disease detection surveys and impact evaluations are expanding to meet the demand for increased information. A hemlock dwarf mistletoe management program is underway in southeast Alaska. Studies to determine the effects of spruce beetles and leaf rollers on birch trees are conducted in cooperation with researchers in south-central Alaska. In interior Alaska, extensive aerial surveys are made to detect insects and diseases. Knowledge gained from these efforts will help all landowners improve their management of forest pests.

The State of Alaska is gradually assuming fire prevention and protection responsibilities for large areas formerly protected by the BLM. Federal assistance to the State for developing adequate forest fire protection capability is made available through Forest Service administration of its Cooperative Forest Fire Control Program for non-Federal lands Activities range from training in basic forestry and engineering techniques to timber cruising and sale preparation, sawmilling and harvesting methods, and balanced management for total resource use. 


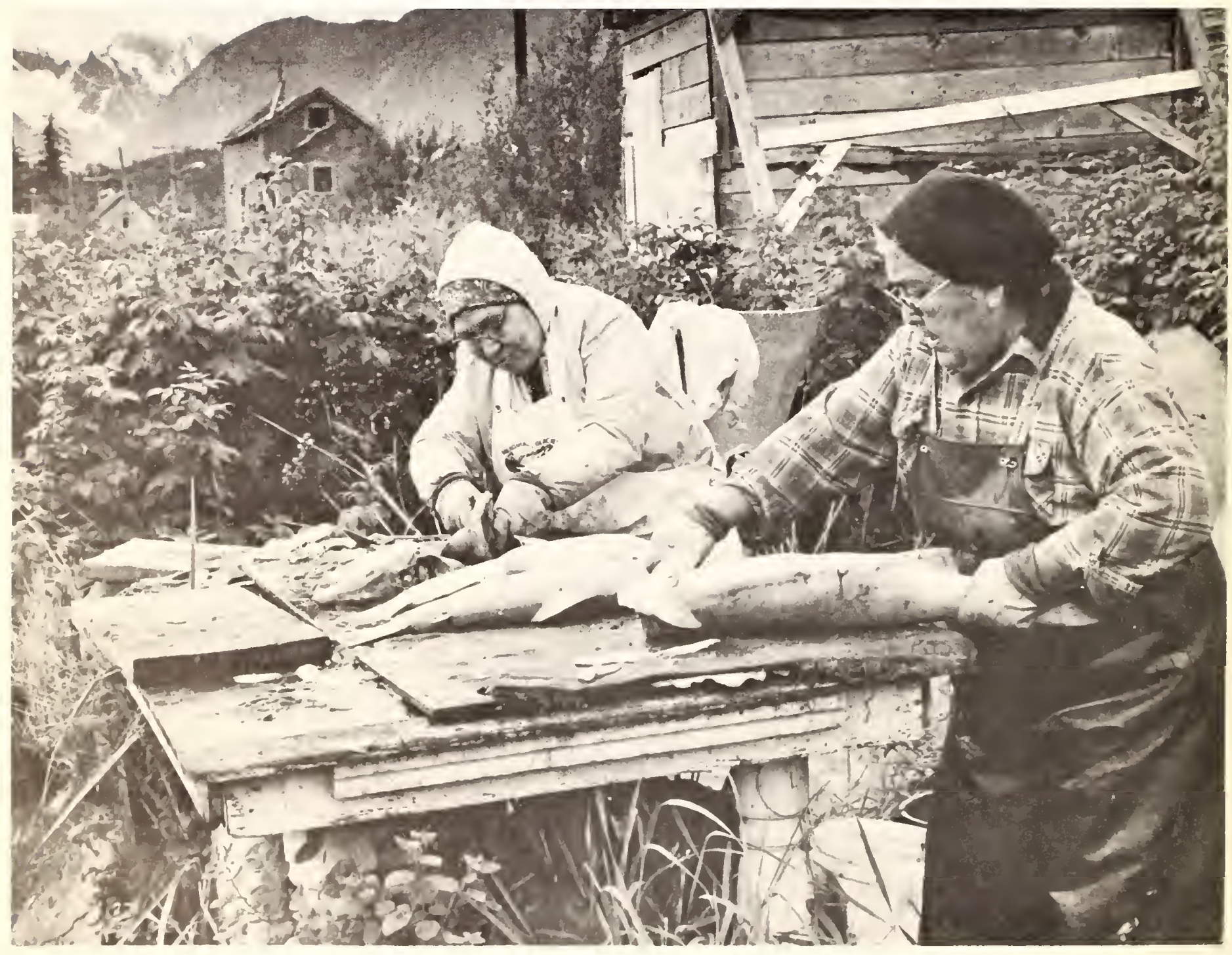




\section{Land Management Planning}

Forest Service activities are directed through legislation and planning. The legislative direction is mainly national in scope, and the planning direction extends from the national level to the local level

The two principal acts that now direct Forest Service planning activities are the Forest and Rangeland Renewable Resources Planning Act of 1974 (RPA) and the National Forest Management Act of 1976 (NFMA). The planning system used in the Alaska Region is hierarchial in nature. It contains four different planning levels, each of which deals with different aspects of the total decisionmaking process.

Directional level - The directional planning level defines how Forest Service responsibilities, legislative mandates, and other binding actions are to be effected. The products of this level are the Forest Service Manual System, the National RPA Program, area guides, and cooperative agreements among different agencies of Government. The scope of this level covers all national forest lands and other rangelands and forests included in the planning areas of the Nation.

\section{Land allocation level-The land}

allocation level complies with directional level decisions to define where combinations of land use opportunities will be made available. Products of the allocation level are land management plans with associated environmental impact statements and forest-wide resource plans. The scope of this level encompasses whole units of the National Forest System.

Prescriptive level-This level defines how management activities and uses that are associated with planned allocations are to be coordinated and controlled. The products of this level are prescriptive plans for specific management areas which direct implementation of planning programs and related environmental analysis reports. The scope of this level is limited to specific areas within the boundaries of a national forest.

Implementation level-The implementation level guides the use of land according to allocation intents and prescriptions. The products of this level are project plans with environmental analysis reports, contracts, and permits. The scope of this level is restricted to sites and routes within specific areas on national forests

In proceeding from the directional level to the implementation level, the scope of each level narrows. The effective lives of the products become increasingly shorter, and the kinds of decisions that are contained in the products become more and more localized and precise. The data needed at each level also vary, ranging from comprehensive and general at the upper levels to situational and precise at the lower levels. Each level plays a distinctive but strongly interrelated role in the decisionmaking process that results in Forest Service management actions on the ground.

\section{Area Guides}

The "Southeast Alaska Area Guide," distributed to the public in April, 1978, is an example of a directional level planning product. The 280-page document contains sections on land management issues, planning direction, land management policies, and the RPA. The guide is the product of a truly participatory approach to planning. A successful public involvement program and a partnership approach to State involvement were used to develop this guide. A similar process was used for south-central Alaska's guide

\section{Forest Land Management Plans}

At the land allocation level, six interagency task forces developed an information base to use in developing a "Tongass Land Management Plan." The plan defined how each of the nearly 800 discrete watersheds that comprise the forest may be managed. It specified where four different kinds of land use designations would be applied in resolving management issues and satisfying different needs and demands. The plan was completed in March, 1979.

A land management plan was developed for the Chugach National Forest in 1974 This plan is being revised and refined to meet the congressional requirements of the RPA and NFMA. The first stage of the revised plan is expected to be completed early in 1980.
Roadless Area Review and Evaluation

A roadless area review and evaluation process formed several proposals for solving roadless area issues in Alaska. These proposals were released in a national environmental statement with State supplements. A heavy reliance on public involvement was used to help resolve roadless area issues. Copies of the final statement are available for review at most regional libraries and Forest Service offices

\section{Interdisciplinary Teams}

At the prescriptive planning level, the regional office staff for planning initiated a series of interdisciplinary team (IDT) training sessions for the management areas. A management problem was designed to actively involve participants in IDT functions. Work is continuing to prescribe and implement current land management plans

\section{Socioeconomic Studies}

Although much of the collected information concerns the physical resources of the forests, human concerns are paramount in any effective planning process A cooperative agreement to study socioeconomic issues was made with the University of Alaska to gain a better understanding of the relationship of forests to people. Under this agreement, the University participated in the development of the socioeconomic elements of the planning process for southeastern Alaska. A similar socioeconomic assessment is being developed for the Chugach National Forest.

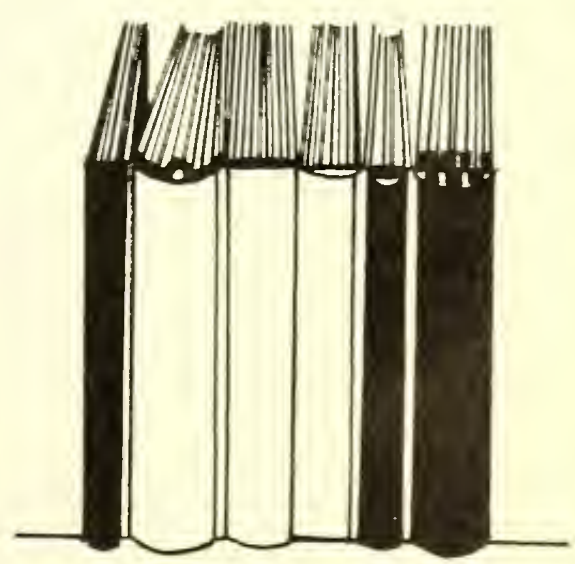


Forest Research in Alaska: Past, Present, and Future

For several decades, research in the coastal and interior forests of Alaska has been conducted by Forest Service scientists at the Juneau and Fairbanks laboratories of the Pacific Northwest Forest and Range Experiment Station. The administrative headquarters of the station is in Portland, Oregon.

Scientists at Juneau began studies of Alaska's coastal forests in 1924. The focus of this early research was on timber yields, forest nutrition, and methods of reforestation following clearcutting These studies continued into the midthirties with little further research until 1948

By 1948, large-scale timber harvests and new pulp mills were proposed for Alaska. These presented new problems and needs for information based on research. The Juneau scientists expanded their program to meet these needs. Emphases were placed on studies of problems created by allowing natural reforestation after largescale clearcutting and on the effects of such logging on aquatic habitats critical to chum and pink salmon.

\section{Research at Juneau}

The work at Juneau involves five principal research areas. Several individual studies are conducted in each area.

Alternative silvicultural practices Sivicultural prescriptions and timber harvesting methods are needed for stream protection, soil and site protection, aesthetics, wildlife, and other considerations. Guidelines are being prepared to cope with problem regeneration areas and sites that are damaged by storm winds.

Wildife habitat - The habitat requirements of many species of game and nongame animals need to be known to assess the effects on habitat of such activities as timber harvesting. Some activities that are destructive to habitat if misapplied may have negligible effects if properly applied. Certain practices may have the potential for improving habitat.

Slope stability - Soil mass movements generated by logging and forest road construction frequently occur in southeast Alaska. They also occur in areas that have not been disturbed. As timber harvesting continues to expand onto increasingly unstable slopes, we need to refine our ability to identify unstable soils and predict effects on downslope resources following debris avalanches and other mass movements. Hazard ratings are being developed for each soil type.

Insects and diseases - insects and diseases are being studied to learn their effects on both old-growth and young stands of spruce and hemlock trees. From this research, guidelines will be developed for preventing or reducing damage by destructive insects and diseases. Work is also underway to enhance the growth and development of spruce seedlings by using selected species of fungi.

Fish habitat - Studies are underway to define the freshwater habitat require ments of anadromous fish. This information will assist land managers in planning timber harvesting and roadbuilding so that damage to the habitat can be reduced or prevented. Other current studies involve analyses of spawning habitat conditions, the effects of low temperatures on fish embryo development and survival, and a method to measure intergravel waterflows.

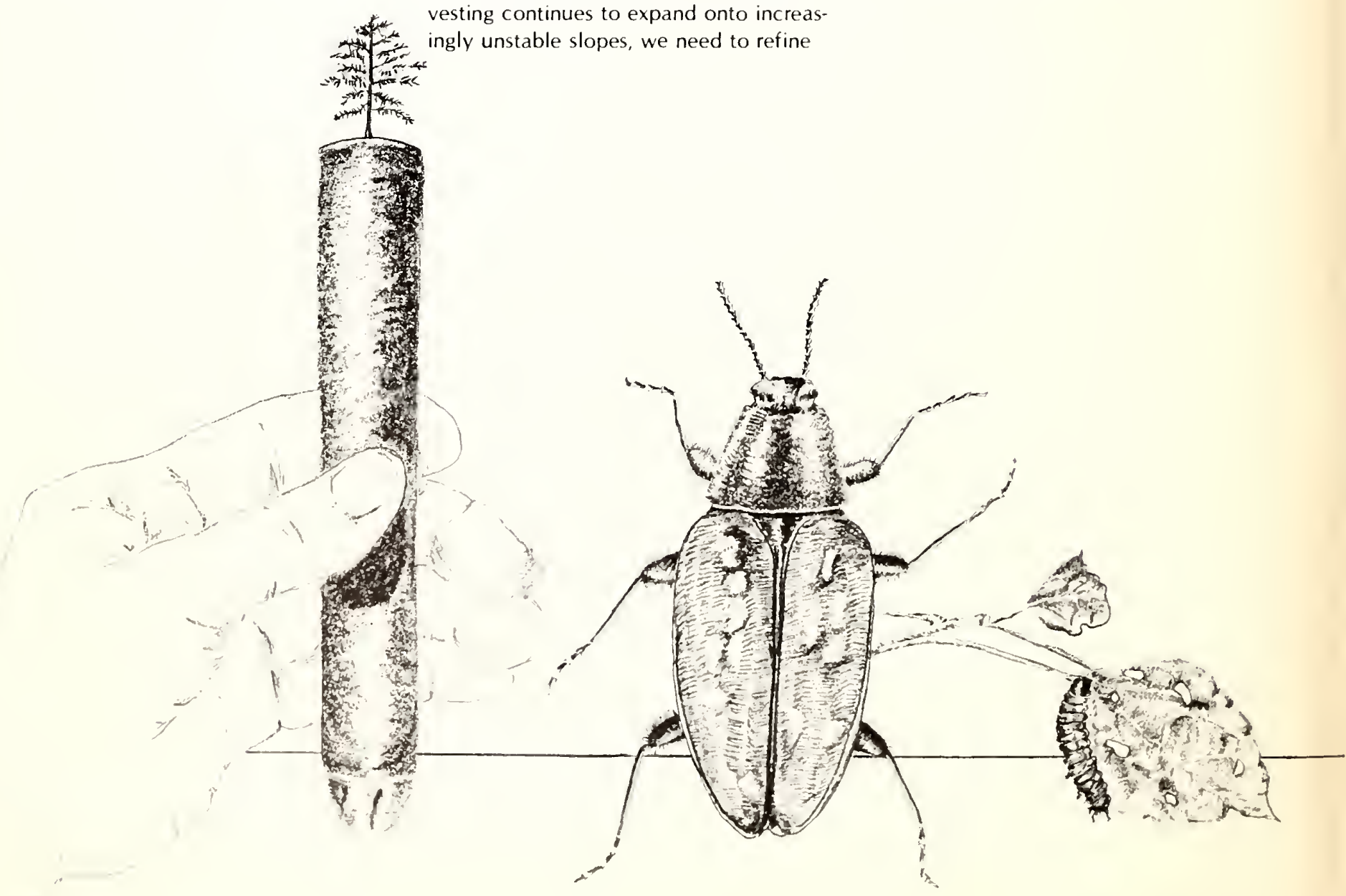




\section{Research at Fairbanks}

Scientists at Fairbanks began studies of Alaska's interior forests, or taiga, in 1957 The focus was centered on studying the reproduction of forest tree species, successional trends of interior forests, and the effects of fire on hydrology and nutrient cycling. These basic studies are continuing. The work at Fairbanks involves five principal research areas with from 5 to 15 individual studies being conducted in each area.

Classifying vegetation - Environmental and forest successional characteristics are being integrated in a classification system for the major types of vegetation in interior Alaska. These studies will eventually provide a sound hierarchical classification system for the types of vegetation in the interior.

Fire effects - The results of the fire behavior study and the effects of fire on taiga and tundra communities will be applied to fire management. This research also provides information to develop guidelines for prescribed burning, to predict conditions that follow wildfires, and to develop models that will give information on the types of fuels which may be expected from various kinds of interior vegetation.
Regenerating vegetation - Strategies are being developed for regenerating and growing trees and shrubs in interior Alaska. Within a few years, as a result of these studies, guidelines will be developed for regenerating white spruce on flood plains and hillsides. Guidelines will also be developed for obtaining natural hardwood regeneration; recommencing spacing between trees in thinning stands of birch, white spruce, and black spruce; and managing the regeneration of vegetation.

Insects - Forest insects are being studied to determine their effects on the regeneration of trees and shrubs on the taiga From this research, guidelines will be developed for indirectly controlling insects, managing spruce beetle attacks, and managing hardwoods and forage that have been defoliated by insects.

Soils and water-This research at Fairbanks involves studies of the relationships of precipitation, runoff, and stream sedimentation in major vegetation types in undisturbed and managed conditions. From this research, guidelines will be developed so that resource managers can reduce erosion caused by timber harvesting in the subartic. Guidelines will also be developed to help determine precipi- tation and runoff relationships on watersheds in serveral tvpes of land use areas Finally, the research will provide a review of existing knowledge about watershed management which will be incorporated in comprehensive guidelines for managing Alaska's interior forests.
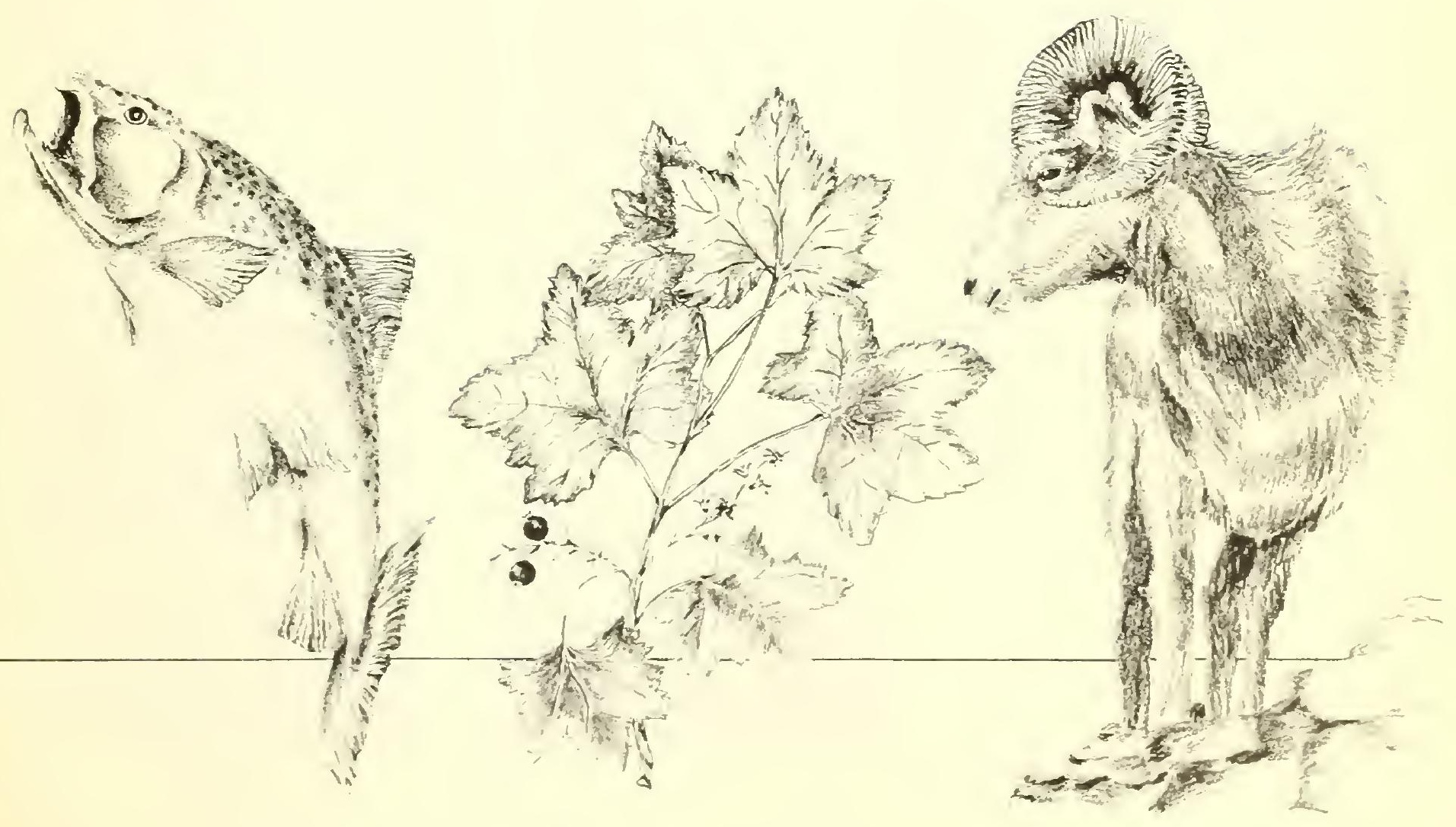


\section{Recreation}

Outdoor recreation and aesthetic values on national forest lands in Alaska comprise a blend of resources and moods unmatched elsewhere. These lands have been described as relatively undeveloped, sparsely populated, water oriented, scenic, rugged, and isolated. They impart a feeling of vastness, wilderness, and freedom to the individual These are the features the Forest Service wants to emphasize in its management of a recreation program in Alaska.

Dispersed recreation, including hunting, fishing, camping, boating, and beachcombing, accounts for 75 percent of all recreational use in national forests in Alaska. The program under the Forest and Rangeland Renewable Resources Act (RPA) specified an increase in dispersed recreation. Alaska can contribute substantially to dispersed recreation, especially in experiences not well represented elsewhere in the Nation.

\section{Recreational Use Patterns}

The Alaska Region is unique for its system of public recreational cabins which are rented to the public by the Forest Service on a reservation basis. The system includes nearly 200 cabins located in picturesque settings throughout the Tongass and Chugach National Forests. Because travelers in Alaska greatly depend on small aircraft or boats for access, the recreational cabins double as a safety feature in the event of poor flying or boating conditions.

On the Kenai Peninsula within the Chugach National Forest, an extensive system of trails with road access links most of the recreational cabins. For areas accessible by road on the two forests, conventional recreational facilities are provided, including 16 campgrounds, 27 picnic areas, and 7 lodges or resorts operated by private interests under permit. The visitor center at Mendenhall Glacier north of Juneau attracts local residents as well as tourists from the many cruiseships plying the "Inside Passage" A major visitor center is planned for Portage Clacier south of Anchorage. All of these facilities, including the recreational cabins, are greatly used. In fact, the Chugach National Forest is used by more visitors than any other national forest, national monument, or national park in Alaska
Wilderness and Other Special Classifications

The Admiralty Island National Monument, between Sitka and Juneau, and Misty Fiords National Monument, east of Ketchikan, were created from the Tongass National Forest by Presidential Proclamation on December 1, 1978. Comprehensive plans are used to manage these monuments. In recognition of their high natural resource, cultural, and scientific values, the Secretary of Agriculture has recommended that both national monuments be classified as wilderness.

About 11.2 million acres of Alaska national forest lands, including both national monuments, were "closed to entry" in November, 1978, under provisions of the Federal Land Policy Management Act (FLPMA). Public use and Forest Service management of these lands will remain much as they are now. For instance, boating, hiking, camping, using cabins, hunting, and fishing with air access will continue under current laws and regulations.

Valid existing land selections by the State and Native corporations are not affected, but no new selections will be permitted. Valid existing mining claims are not affected, but the lands are closed to further mineral entry. Fish and game resources are still being managed in cooperation with the State of Alaska.

Most of the areas affected by the FLPMA action are roadless. The action will apply until November, 1980, unless Congress provides other direction.

The Forest Service in Alaska has taken many actions over the years to recognize and protect the outstanding natural features occurring on national forest lands. The following areas have been given a special classification to assure this recognition and protection:

- Portage Clacier Recreation Area $(8,600$ acres $)$

- Mendenhall Glacier Recreation Area, established in 1947 (5,660 acres).

- Ward Lake Recreation Area, established in 1948 (160 acres).

- Limestone Inlet Natural Area, established in 1951 (6,439 acres).

- Old Tom Natural Area, established in 1951 (4,727 acres).
- Pack Creek Research Natural Area, established in 1951 (5,800 acres), now part of Admiralty Island National Monuments.

- Walker Cove-Rudyerd Bay Scenic Area, established in 1952 (93,540 acres), now part of Misty Fiords National Monument

- Tracy Arm-Ford's Terror Scenic Area (283,000 acres). This was originally proposed by the Forest Service for classification as a wilderness in 1954. During hearings, this classification was strongly opposed and the proposal was set aside. In 1960, the Secretary of Agriculture classified it as a scenic area.

- Cape Fanshaw Natural Area, established in 1965 (600 acres).

- Admiralty Lakes Recreation Area, established in 1965 (11,000 acres), now part of Admiralty Island National Monument.

- New Eddystone Rock Ceological Area, established in 1966 (1 acre).

- New Kasaan Totem Park

Archeological Area, established in 1966 (11 acres).

- Fish Creek Recreation Area, established in 1972 (8,710 acres).

- Dog Island Natural Area, established in 1976 (744 acres).

- Young's Bay Experimental Forest on Admiralty Island.

- Pack Creek Bear Preserve, now part of Admiralty Island National Monument.

- Thayer Mountain Bear Preserve, now part of Admiralty Island National Monument.

- Stikine River, Seymour Canal, and Copper River Wildlife Management Areas.

In addition to those classified areas, the Forest Service, in its first roadless area review, identified seven wilderness study areas totaling 2.6 million acres. More recently, a second Roadless Area Review and Evaluation (RARE II) process identified additional lands to be classified as wilderness. Certain public lands adjacent, but not now part of a national forest, have also been considered for inclusion in the National Wilderness Preservation System. The total area of land recommended for wilderness exceeds 7 million acres in Alaska Table I shows the approximate size of each area recommended for the wilderness classification. 

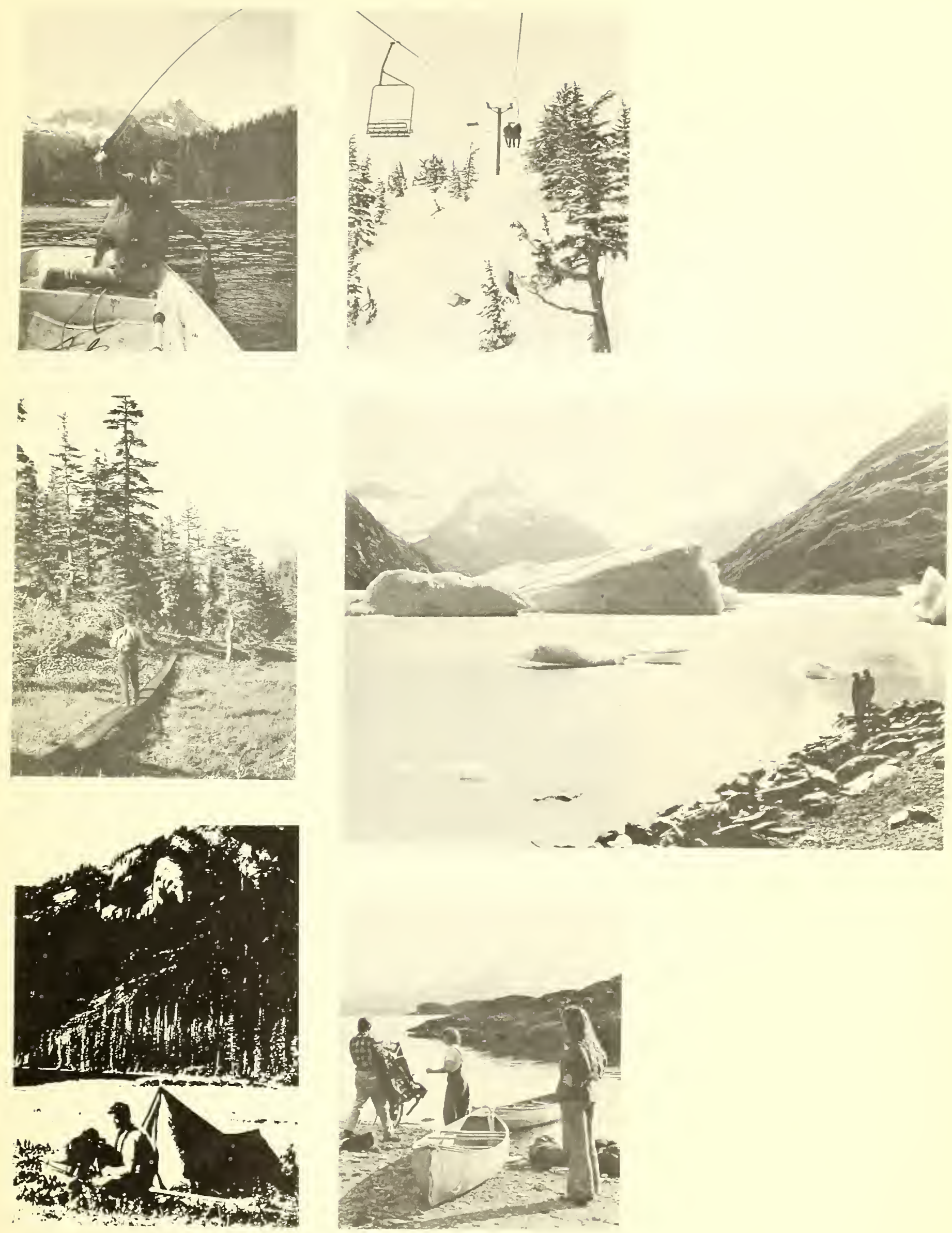
Table I-Alaska natıonal forest areas recommended for wilderness classification and their approximate sizes

\begin{tabular}{|c|c|c|c|}
\hline \multirow[b]{2}{*}{ Area name } & \multicolumn{3}{|c|}{ Size of lands recommended for wilderness from: } \\
\hline & $\begin{array}{c}\text { Existing } \\
\text { national } \\
\text { forest } \\
\text { lands }\end{array}$ & $\begin{array}{c}\text { Other } \\
\text { Federal } \\
\text { lands }\end{array}$ & $\begin{array}{c}\text { Total } \\
\text { Federal } \\
\text { lands }\end{array}$ \\
\hline & \multicolumn{3}{|c|}{ Thousand acres } \\
\hline Alaska Region & 6,1703 & $1,389.6$ & $7,559.9$ \\
\hline Chugach National Forest & 770.0 & 893.0 & $1,663.0$ \\
\hline College Fiord & 1710 & 612.0 & 783.0 \\
\hline Nellie Juan & 478.0 & 281.0 & 759.0 \\
\hline Devilpaw & 570 & - & 57.0 \\
\hline Tonki Cape & 64.0 & - & 64.0 \\
\hline Tongass National Forest & $5,400.3$ & 496.6 & $5,896.9$ \\
\hline Russell Fiord & 295.0 & 37.0 & 332.0 \\
\hline Admiralty Island & 921.0 & - & 921.0 \\
\hline West Chichagof-Yakobi & 2270 & - & 2270 \\
\hline Stikine-LeConte & 275.5 & 144.8 & 420.3 \\
\hline Tracy Arm-Ford's Terror & 506.6 & 149.6 & 6562 \\
\hline Boundary Spires & 128.3 & 165.2 & 293.5 \\
\hline Misty Fiords & $2,285.0$ & - & $2,285.0$ \\
\hline Endicott River & 103.0 & - & 1030 \\
\hline Petersburg Creek & 27.0 & - & 27.0 \\
\hline South Baranof & 305.0 & - & 305.0 \\
\hline Tebenkof & 65.0 & - & 65.0 \\
\hline Coronation Islands & 19.1 & - & 19.1 \\
\hline Warren Island & 11.4 & - & 114 \\
\hline Maurelle Island & 4.4 & - & 44 \\
\hline Karta & 39.0 & - & 39.0 \\
\hline Etolin IsIand & 91.0 & - & 91.0 \\
\hline Prince of Wales Island & 97.0 & - & 97.0 \\
\hline
\end{tabular}

\section{Cultural Resources}

About 1,200 historical and archeological sites have been inventoried near Prince William Sound, on the eastern Kenai Peninsula, and throughout southeast Alaska. Most of these sites are now on National Forest System lands. They vary greatly in age, ranging from 10,000-yearold archeological sites to installations of the World War II era. Their types vary, too, and include historic and prehistoric Native villages and campsites, historic mines, canneries, fox farms, and homesteads. Many of these sites will become private property as landownerships are conveyed to the State of Alaska or to Native corporations.

As timber harvesting and other grounddisturbing activities increase in the Alaska Region, the chances for discovering new historical or archeological sites will increase. And, the chances for their destruction or disturbance will grow.

The value of these cultural resources, the danger of their destruction, and Forest Service legal obligations to enforce Federal antiquities laws prompted the Alaska Region to hire its first archeologist in 1974. Since that time, the needs for archeological surveys have increased, and additional specialists have been hired.

\section{Visual Resources}

Scenic or visual resources are among the most important assets of the national forests in Alaska. For that reason, scenic resources are managed separately in a manner similar to management of timber, wildlife, and recreational resources.

Forest landscape architects use the National Visual Management System to inventory, evaluate, and help set visual quality objectives for all areas of Alaska's national forests. Visual quality objectives are based on public use sensitivity (travel routes and use areas) as well as scenic quality of the landscape. These visual quality objectives are used in project plans, including recreational and administrative sites, timber sale areas, wildlife and fisheries habitat enhancement projects, and utility and transportation corridors 


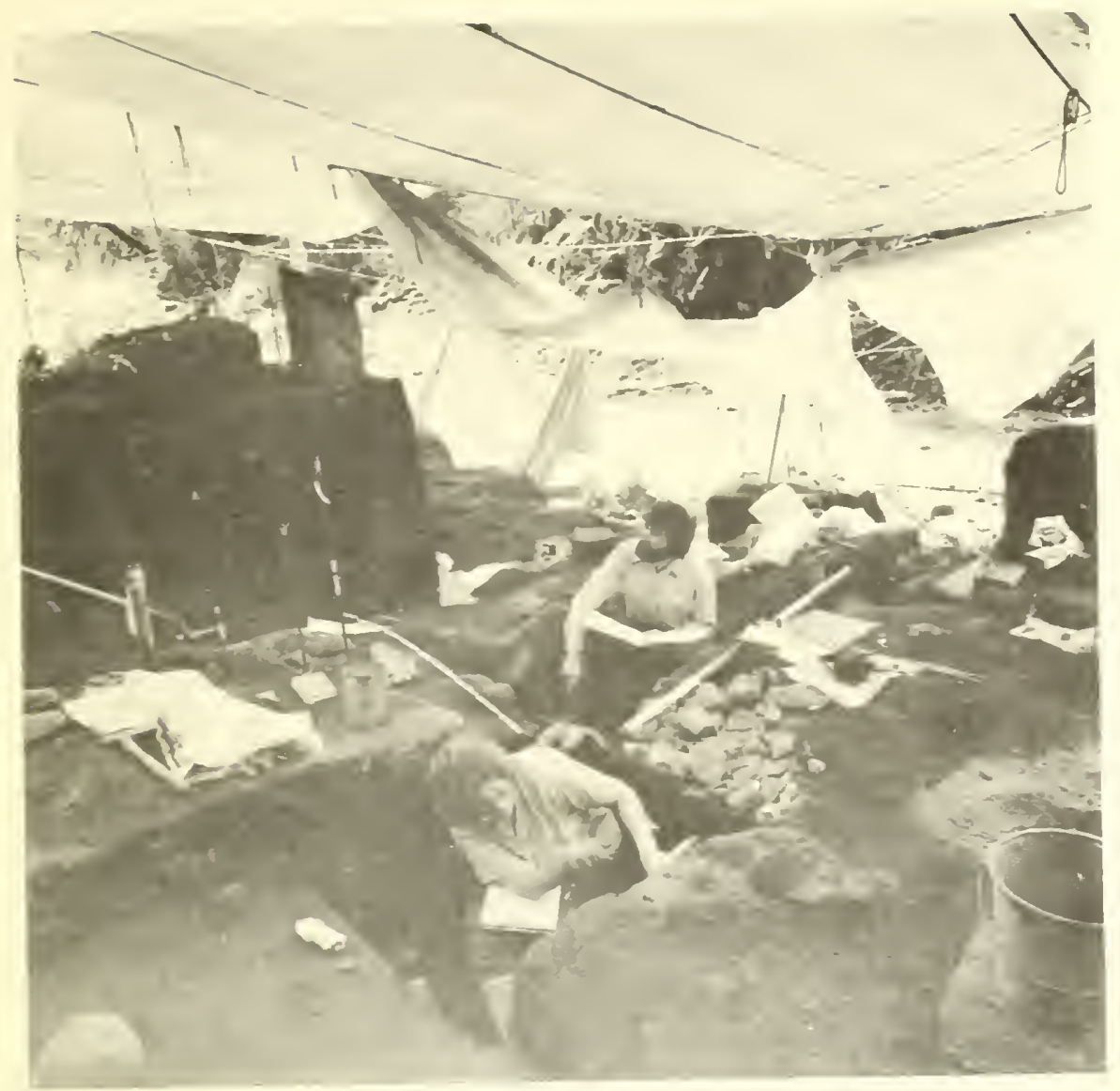

Hidden Falls archaeological "dig" near Sitka, Alaska.
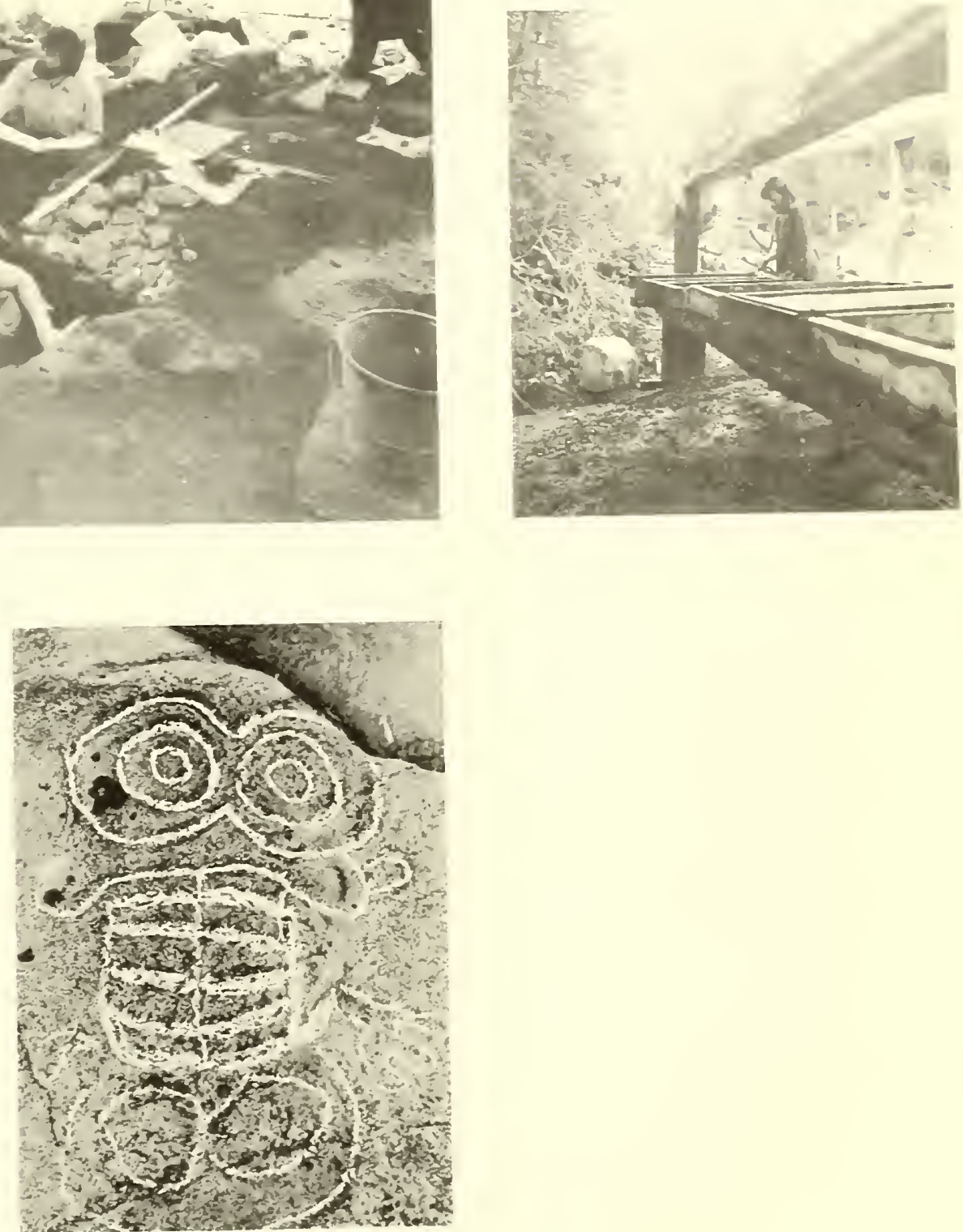


\section{Fisheries and Wildlife}

The first Forest Service wildlife biologist was hired in. Alaska in 1960, and another was added in 1961. Today, there are 36 wildlife and fisheries biologists in the region, not including research biologists. Additional biologists may be recruited to assist with expanded land management planning and related field administrative work

The work of the biologists consists of participating in land management planning, coordinating management of fish and wildlife resources with timber, and improving habitat. They work closely with biologists of the Alaska Department of Fish and Game (ADF\&G) and other agencies to assure coordination of the respective responsibilities of these organizations in the national forest areas

\section{Surveys and Studies}

Administrative studies are being conducted by Forest Service biologists in cooperation with research scientists and research projects by scientists from other State and Federal agencies. These studies are closely related to fisheries and wildlife habitat management and are designed to provide information to meet management needs of resource specialists. They include-

- A complete inventory of fish has been done in cooperation with ADF\&G An inventory of needed stream improvement projects is being done for each area.

- The National Marine Fisheries Service (NMFS), cooperating with the Forest Service, has completed a survey of deactivated log transfer sites on part of the Tongass National Forest to determine persistence of bark accumulation and its effects on estuarine life. This work is continuing on additional sites.

- On the Copper River Delta, the University of Alaska is conducting a study of the breeding habits of the dusky Canada goose. The University of Minnesota and the Forestry Sciences Laboratory are studying the changes in the habitat and vegetation composition resulting from the 1964 earthquake.

- The inventory of bird species and habitat for the Alexander Archipelago is continuing with an emphasis on nongame species
- A preliminary survey identifying critical deer winter range by soil ecosystem type was completed by biologists and soil scientists of ADF\&G and Forest Service on the Chatham and Stikine Areas of the Tongass. Results of this study will help provide guidance for design of clearcut shape and size to increase browse production. An evaluation of deer range and habitat use, done by ADF\&G and the Forestry Sciences Laboratory, has provided insight into some of the effects of timber harvesting on deer habitat.

- In the Stikine Waterfowl Management Area, several studies and an intensive habitat inventory are in progress. A report by the University of Washington botany team studying vegetative succession has been prepared. Studies have been initiated on moose browse in the delta, and waterfowl use surveys are continuing

- The Quartz Creek-Kenai Prescribed Burn Administrative Study, begun in cooperation with ADF\&G, is continuing to analyze fire techniques, study the effects of fire on Kenai Peninsula vegetative types, and evaluate the techniques to improve moose habitat.

\section{Effects of Timber Harvesting}

One of our most important activities is providing wildlife and fisheries support to ensure the protection of fish and wildlife values during other resources uses, such as timber sales programs. A serious potential for significant adverse effects from timber harvesting exists for fisheries, wildlife, and watershed values. Evidence that significant damage has actually taken place has not been well documented. Much of the damage appears to be a direct or indirect result of the limited resource information available or of personnel to ensure proper timber sales administration.

Today, expertise in the fields of fisheries, wildlife, and watershed management is much greater than 10 years ago. About 70 biologists, soil scientists, and hydrologists now work for the Forest Service in Alaska. These people are actively involved in several programs designed to yield a better understanding of the natural environment, thereby reducing or eliminating unacceptable environmental changes. These programs include resource inventories and

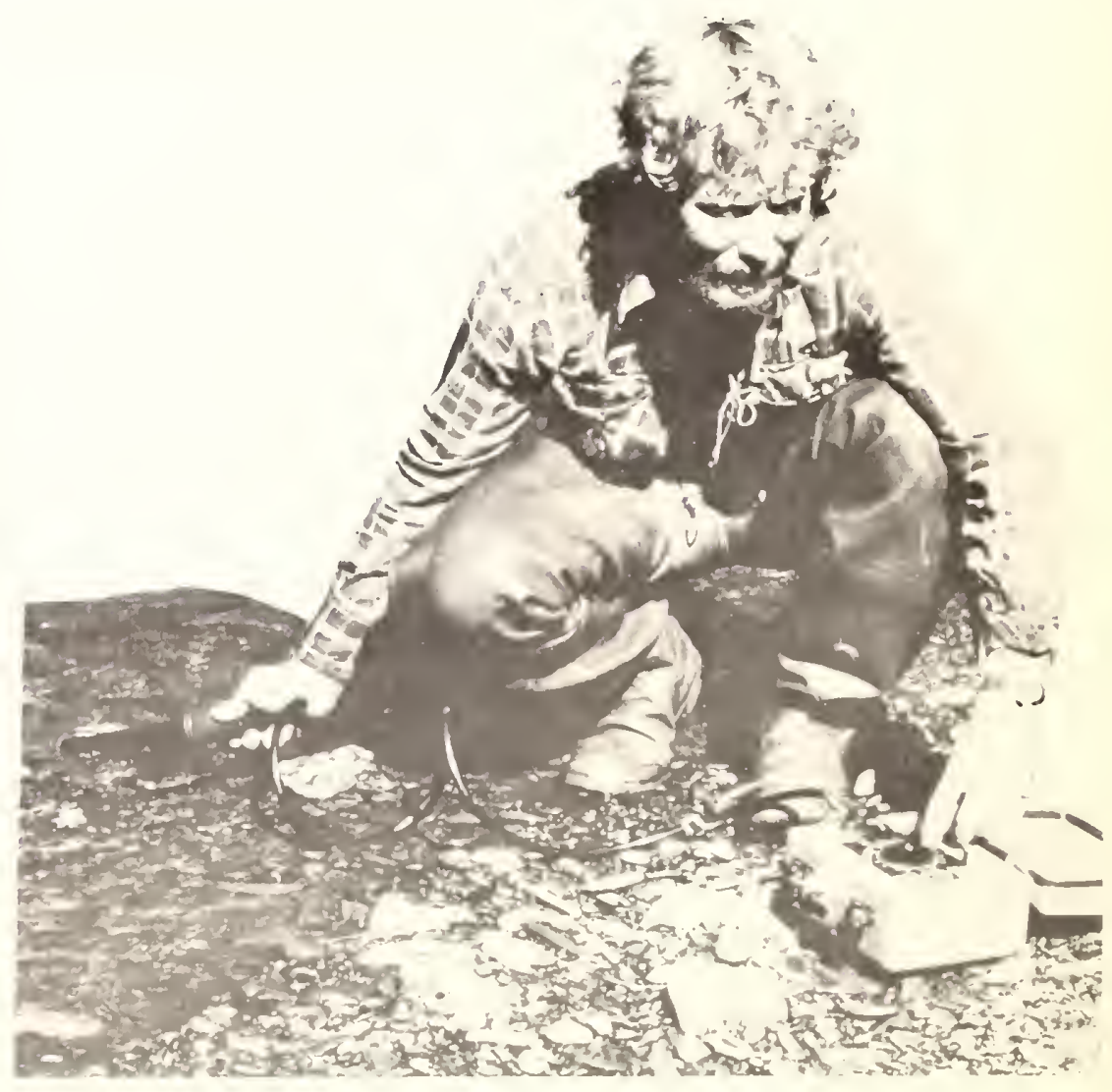


monitoring activities, interdisciplinary team (IDT) analyses, and development of prescriptions for the protection and management of the fisheries resource. The rest of this section and parts of the timber, soil, and water sections describe many of the other programs designed to reduce adverse environmental effects that may occur on national forest lands.

Although quantitative evidence of significant damage because of logging is lacking, qualitative evidence shows that damage can be caused by sedimentation, changes in the temperature regimens of streams, and other human-caused occurrences. With a good knowledge of the habitat requirements of salmonid fishes, land management planning may now include sound prescriptions for protecting the fishery resource.

The importance of small streams for rearing species of fish was only recently recognized. Protection measures are now prescribed to lessen or prevent damage. Proper size, shape, and installation of culverts and bridges in road construction is essential to passage of fish. A strong program has been developed to correct existing installations where necessary and to assure proper installations in the future.

Deer survival depends on critical winter range, and special studies and provisions have been made to identify and protect this range. Studies are also underway to

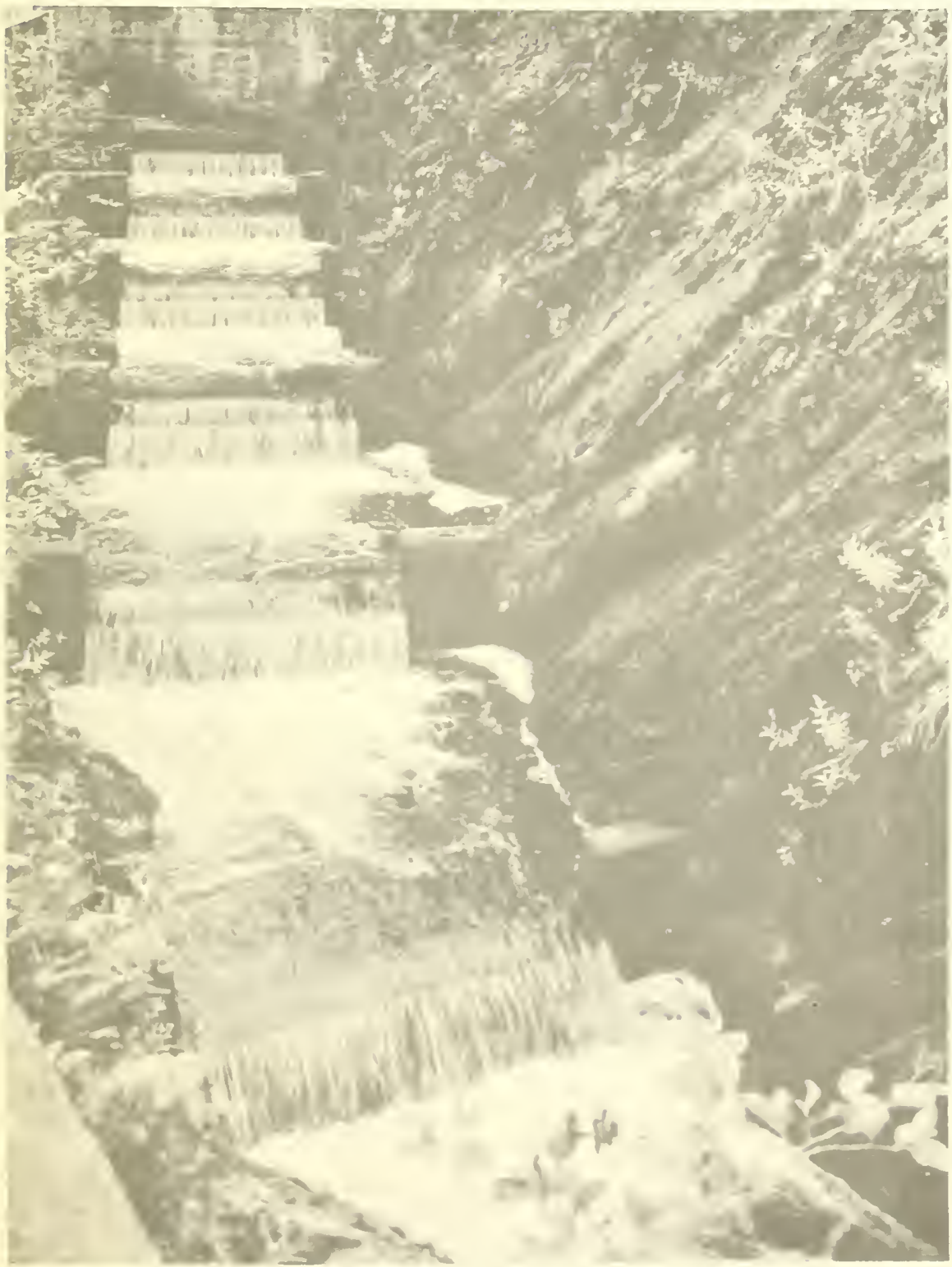

determine the needs of mountain goats during the winter and whether timber harvesting practices in goat country need to be modified. A reassessment of the adequacy of the "buffer strip" around eagle nesting trees is being considered. And, it has been determined that timber harvesting does not appear to significantly affect either brown or black bears.

\section{Habitat Improvements}

The fish habitat improvement program started in 1962. Since that time, more than 200 projects have been completed on the Chugach and Tongass National Forests. The Forest. Service and ADF\&C have almost equally shared the costs.

Wildlife habitat improvement is receiving more emphasis. Prescribed burning is being conducted on the Kenai Peninsula to increase forage for moose on about 20,000 acres.

Stream improvement and rehabilitation projects have included fishway construc tion, developing coho salmon rearing ponds, fish planting, and stream clearance through debris removal. Most of the projects are intended to protect and enhance habitats of the five salmon species that provide significant economic and social benefits to the State, but they also reflect a growing demand for quality sport fisheries.

\section{Land Allocations}

The creation of Admiralty Island and Misty Fiords National Monuments did not affect wildlife and fisheries programs But, the pending designation of wilderness areas under the RARE II and Administration legislative proposals has precluded some habitat improvement projects in the Chugach and Tongass National Forests. State and Native land selections also have affected this program to some extent.

\section{Cooperation with Other Agencies}

Many cooperative efforts are carried on in Alaska among the Forest Service and other agencies. There are cooperative agreements with ADF\&C, NMFS, U.S. Fish and Wildlife Service, BLM, and other agencies and a master Memorandum of Understanding with the ADF\&C to help 
coordinate management of fisheries and wildlife resources within Alaska.

The Sikes Act provides an excellent opportunity for cooperative wildlife and fisheries program between the Forest Service and the State of Alaska. A cooperative fish and wildlife habitat management plan was prepared in 1976 by the Forest Service and the ADF\&G. This plan identified a high priority program that will be implemented as rapidly as funding is available. In developing this program, it was possible to illustrate the extremely high benefit-to cost ratio that would be realized from many of the project proposals.

The Copper River Delta Wildlife Management Area was created by a Cooperative Agreement, signed April 5, 1962, by the Forest Service, ADF\&G, and the Alaska Department of Natural Resources (ADNR). The management objectives of the game management unit is to maintain the habitat in its present quality and condition and to enhance the habitat where needed A similar agreement established the Stikine River Wildlife Management Area early in the sixties.

The Portage Wildlife Habitat Management Area (Chugach) is under the cooperative management of the Forest Service, BLM, ADF\&G, ADNR, Alaska Department of Highways, and the Alaska Railroad. It was designated in 1976 and is an excellent example of providing wildlife opportunities for both comsumptive and nonconsumptive users.

\section{Stream Management}

Removing vegetative canopy from some streams, especially the smaller ones, can result in increased temperatures during the summer. This is especially true in the southern part of the Tongass. Excessive amounts of limbs, bark, and needles in stream channels can also adversely affect the spawning and rearing habitat of salmonid fishes. Guidelines have been developed to prescribe cutting patterns along these streams and protect them against temperature increases. The guide lines also help to prevent an adverse accumulation of debris in streams

Forest Service practice favors site-specific prescriptions. The "Southeast Alaska Area Guide" contains a detailed description of fish and wildlife management issues, goals, and policies. They are also discussed in the "Tongass Land Management Plan."

\section{Threatened and Endangered Species}

The Forest Service is cooperating with the U.S. Fish and Wildlife Service in the Aleutian Canada goose studies. Forest Service personnel are given descriptions and photographs of the birds and are encouraged to report sightings.
Throughout the region, emphasis is placed on protecting critical habitat and species identification. Our objective is to preclude any species from becoming endangered. A threatened and endangered plant program has been started in the region to determine if any such plants occur on national forest lands.

\section{Aquaculture}

Forest Service fisheries biologists are increasingly involved in preparing environmental impact statements for proposed salmon aquaculture facilities. Biologists and other Forest Service personnel have also been involved in interagency aquaculture workshops, public hearings on proposed sites, and familiarization tours of existing facilities

The identification of aquaculture sites is an important part of the current land management planning process. Where State, Federal, and private aquaculture organizations note promising opportunities for permanent aquaculture developments, the sites will be designated and provisions taken to encourage development
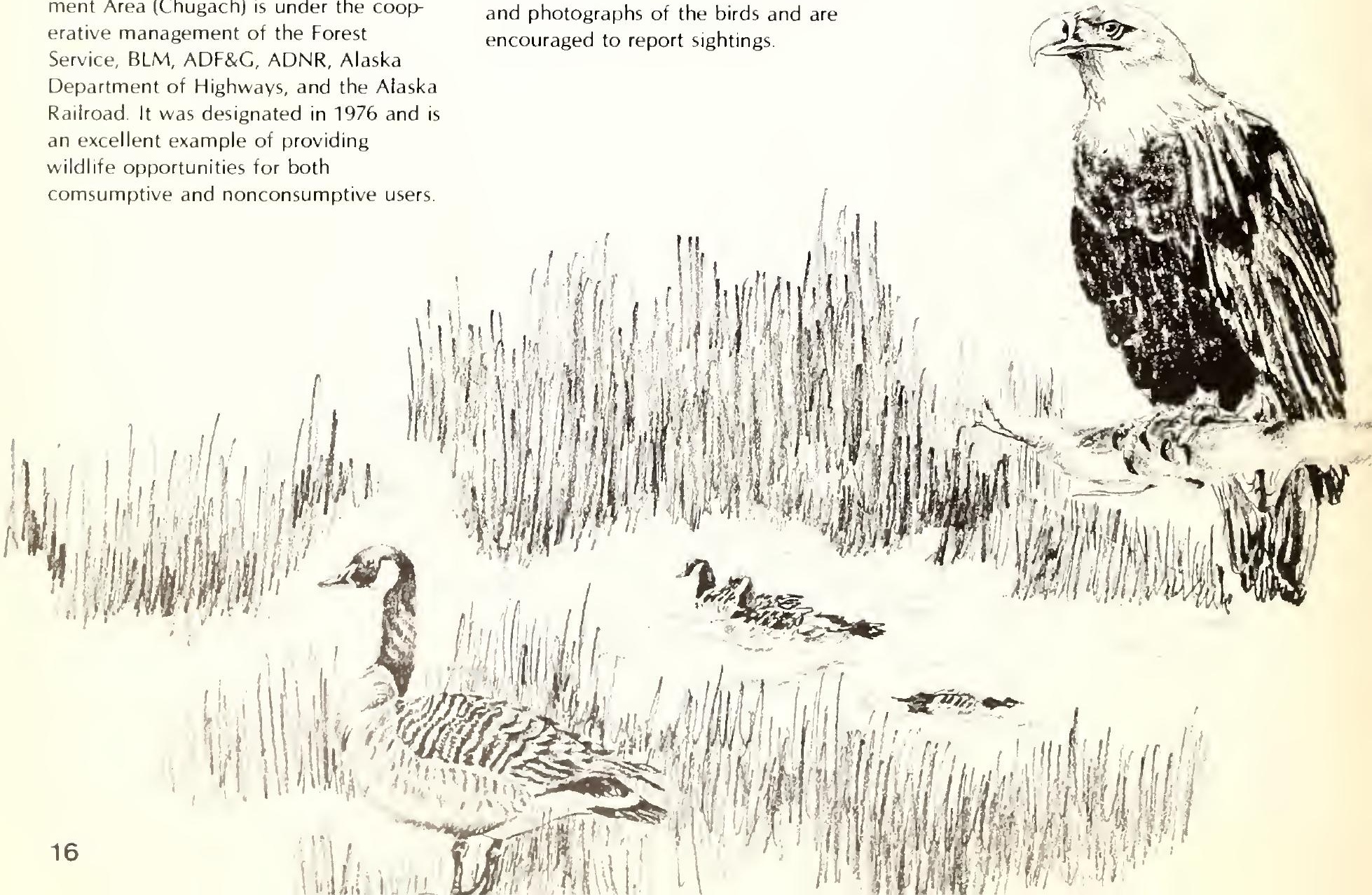


\section{Timber Management}

Coordinating a timber management program with management of other important resource values is one of the most challenging Forest Service responsibilities in Alaska. In addition to the importance of the timber resource to the general economy, there is a good opportunity to use the timber program to actually enhance other values. At the same time, it must be recognized that a potential exists for conflict with and damage to other resources, unless great care is practiced

\section{Reforestation and Sale Area Improvement Program}

In coastal Alaska, logging is generally followed by an abundance of Sitka spruce and western hemlock regeneration. But, in some areas and under some site conditions, natural regeneration does not occur rapidly enough to obtain satisfactory stocking within a 5 -year period. It may be necessary to plant these areas to meet National Forest Management Act requirements for establishing regenerating stands.

Timber has been harvested from about 300,000 acres in the national forests in Alaska. Results of stocking surveys indicate a backlog of 7,000 acres inadequately stocked. Small areas needing reforestation will occur each year from harvesting.

The region has established a forest tree nursery near Petersburg. It is a greenhouse complex capable of growing a million containerized seedlings each year on a one-crop-per-year basis. The initial phase in 1979 produced about 150,000 seedlings. Full production is expected by 1981. Our current plans are to obtain all trees needed for the Chugach from the State nursery near Palmer, Alaska.

The overabundance of natural regeneration that occurs on most harvested areas can benefit from early thinnings. This will benefit wildlife habitat and increase harvestable timber growth.

The precommercial thinning program was started in 1974 with 244 acres thinned by contractors. By 1977, this had increased to 2,168 acres. Areas harvested 10 to 20 years ago benefit the most from this thinning. We anticipate building to a program of 7,000 acres a year during the next decade.

Hemlock dwarf mistletoe is prevalent in southeast Alaska. British Columbia estimates an annual loss of 150 million cubic feet of wood to this parasite through increased mortality and decreased growth of infected trees. Since western hemlock trees comprise about 75 percent of old-growth stands and a slightly smaller percentage of younggrowth stands, control of dwarf mistletoe is an important factor in timber management. A control program was started in 1967. Since that time, 14,000 acres have been treated in the Tongass National Forest. This parasite does not exist on the Chugach National Forest.

\section{Stream Protection}

Commercial fishing and timber harvesting are very important to the economy in southeast Alaska, and use of these resources are in some cases difficult to coordinate. Timber sale cutting units and road systems must be designed to protect the streams. Improperly conducted timber harvesting can adversely affect stream water temperatures

Clearcutting adds to the amount of nutrients available in the soil. It also increases the amount of rainfall that reaches the ground where the runoff can carry the nutrients to the streams. Studies show that only moderate amounts of nutrients are added to the streams by timber harvesting in Alaska. This leaching is lessened here, because the rapid regrowth after logging quickly increases the rainfall interception and water use by plants. The added nutrients that do reach the streams may be beneficial in Alaska, as nutrient levels in many southeast Alaska streams are quite low under natural conditions. But, the added nutrients can have an adverse effect on the fisheries habitat if they cause an excess production of algae in the stream.

The "Southeast Alaska Area Guide" provides detailed stream protection requirements, and these have been implemented. A comprehensive examination and reconstruction program is underway in southeast Alaska to survey and, where necessary, to correct unsatisfactory culvert and bridge installations that may be impeding the passage of fish in streams.

\section{Timber Sale Administration}

The timber sale contract is an instrument for implementing resource coordination requirements. Supervising the activities related to timber harvesting is the responsibility of resource management assistants (RMAs). There are about 40 RMAs and Sale Administrators working in timber sale administration. In addition, about 30 engineers and engineering technicians supervise the construction of the roads needed for harvesting.

About 50 timber harvesting operations take place on the Tongass and Chugach National Forests from April through November. The frequency of sale administration visits to a sale area depends on the size and complexity of the operation and the timing of critical phases, such as bridge construction over a salmon stream. Sale administrators and engineering personnel work on some sales full time, but other sales are administered by periodic inspections

Since the turn of the century, about 300,000 acres have been harvested on the national forests in Alaska. The land management planning process will determine how much of the commercial forest acreage will be harvested. Based on the ranges for potential yield established in the "Tongass Land Management Plan," about 2 million acres of the Tongass could provide a timber crop in addition to other resource values. This is about a quarter of the total commercial forest land.

Not all of the estimated 2-million acres would be harvested during a normal 100 -year rotation period. Parts would receive a modified harvesting treatment (other than standard clearcutting practices) because of special considerations needed to accommodate other resource values. In some cases, this would include a considerable lengthening of the normal 100-year rotation. Our best estimate, pending refinement of data from the "Tongass Land Management Plan," is that timber harvesting of some kind will take place on about $1,550,000$ acres of the Tongass during a 100-year period. On the Chugach, we would expect to harvest timber from about 50,000 acres in such a rotation period

For resource protection, some of the potential timber yield will come either 
from stands that require more sophisticated logging techniques than are currently in common use in Alaska or from areas that are now marginally economical to harvest. Improved economic conditions and increased wood fiber demand could make "marginally economical" timber attractive to log, even with conventional logging equipment. A satisfactory economic climate and the increased use of these new logging systems, such as helicopter, balloon, and other full-suspension systems, are necessary if the projected yield is to be realized.

\section{Long-Term and Independent Timber Sale Programs}

Four long-term sales have been awarded on the Tongass to bring economic development and stability to southeast Alaska. These are the 1951 Ketchikan Pulp Company (KPC) sale, now owned by Louisiana-Pacific Corporation, Ketchikan Division (LPK); the 1954 Pacific Northern Timber sale (PNT), which expires in December, 1981; the 1957 Alaska Lumber and Pulp Company sale (ALP); and the 1968 Juneau Unit sale, which was never operated and was cancelled by mutual agreement between the purchaser, Champion-International, and the Forest Service in June, 1976. The two 50-year sales (LPK and ALP) were validated by the National Forest Management Act of 1976.

The design for timber harvesting of these sales is based on 5-year operating periods. For each period, the timber sale contract is examined and the value of the included timber is appraised so that, within contractual limitations, current conditions, including new environmental and utilization requirements, may be met. Additionally, the National Forest Management Act specifically provides that at the time of the 5-year rate redetermination on the two 50-year sales, we are to revise the contracts to conform to requirements of the Resources Plannıng Act of 1974, as amended by the National Forest Management Art of 1976. The independent sale program will offer about $161 \mathrm{MM}$ bm for sale in fiscal year 1979/80.

Timber sold from the national forests must be sold for not less than the appraised value. The Forest Service establishes the fair market value, based on the costs, returns, and profit margins of the average operator. The Alaska

Region uses an accountant-forester engineer team to collect cost data from the timber sales. (See the section

"Balance Sheet of the Alaska Region" for information about timber sale receipts for national forest products and about equity increases.)

Southeast Alaska communities with a great dependence on the timber industry include Haines, Kake, Ketchikan, Klawock, Metlakatla, Petersburg, Sitka, and Wrangell. Currently, about 5,300 jobs, in both the public and private sectors, are directly or indirectly related to the timber products industry in southeast Alaska. Timber industry related jobs make up about 29 percent of southeast Alaska's employment.

During the last 10 years, the number of small timber businesses operating in southeast Alaska has steadily declined. Both small and large businesses believe the advertised stumpage rates are too high, and small businesses have expressed concern about their inability to sell pulp logs and chips to local pulpmills.

The Regional Forester, after public hearings, took several actions to help small businesses develop a viable economy. The Regional Forester and the Small Business Administration signed a share agreement which annually will set aside approximately $80 \mathrm{MM}$ bm of timber on the Tongass National Forest and 5 MM bm on the Chugach for purchase by small businesses. The volume planned for the fiscal year 1979/80 "set aside" program is $115 \mathrm{MM} \mathrm{bm}$. The export of chips manufactured from sawlogs is now permitted.

\section{Allowable Timber Harvest Levels}

The allowable timber harvesting volume from Alaska's national forests depends on several variables. These include the productivity of the forest, current logging technology, such practices as fertilization and thinning, and the interrelationship with other forest resources and the environment.

The programmed harvest estimated for the next 10 years (adjusted for anticipated Native and State land selections) for the Tongass National Forest is $\mathbf{4 5 0}$ MM bm a year. The Chugach land management plan is now being developed, and the programmed harvest will be determined through the adopted plan.

The Tongass harvest is based on the selected alternative as shown in the "Tongass Land Management Plan" final environmental statement released in March, 1979. The $450 \mathrm{MM}$ bm is based on the assumption that an additional $\$ 11.7$ million a year will be appropriated by Congress for advanced roading and timber stand improvements (thinning of at least 6,300 acres a year) in regenerated stands.

The timber industry in southeast Alaska has said that present manufacturing facilities are geared to handle about 660 million feet board measure ( $\mathrm{MM} \mathrm{bm}$ ) a year. No definite figures are available on the Chugach because of a lesser demand. Table 2 shows the amount of timber released for harvesting in recent years on the long-term sales or advertised for sale as part of the independent sale program, as well as the volumes of timber actually harvested in recent years.

Table 2-Offered and actual amounts of timber harvested

\begin{tabular}{ccc}
\hline $\begin{array}{c}\text { Fiscal } \\
\text { year }\end{array}$ & $\begin{array}{c}\text { Volume } \\
\text { made } \\
\text { available }\end{array}$ & $\begin{array}{c}\text { Volume } \\
\text { harvested }\end{array}$ \\
\hline $1973 / 74$ & 395 & MM bm \\
$1974 / 75$ & 430 & 593 \\
$1975 / 76$ & 710 & 561 \\
$1976 / 77$ & 555 & 469 \\
$1977 / 78$ & 555 & 449 \\
$1978 / 79$ & 557 & 465 \\
$1979 / 80$ & 606 (Planned amount) & 430 \\
$1980 / 81$ & 529 (Planned amount) & - \\
\hline
\end{tabular}



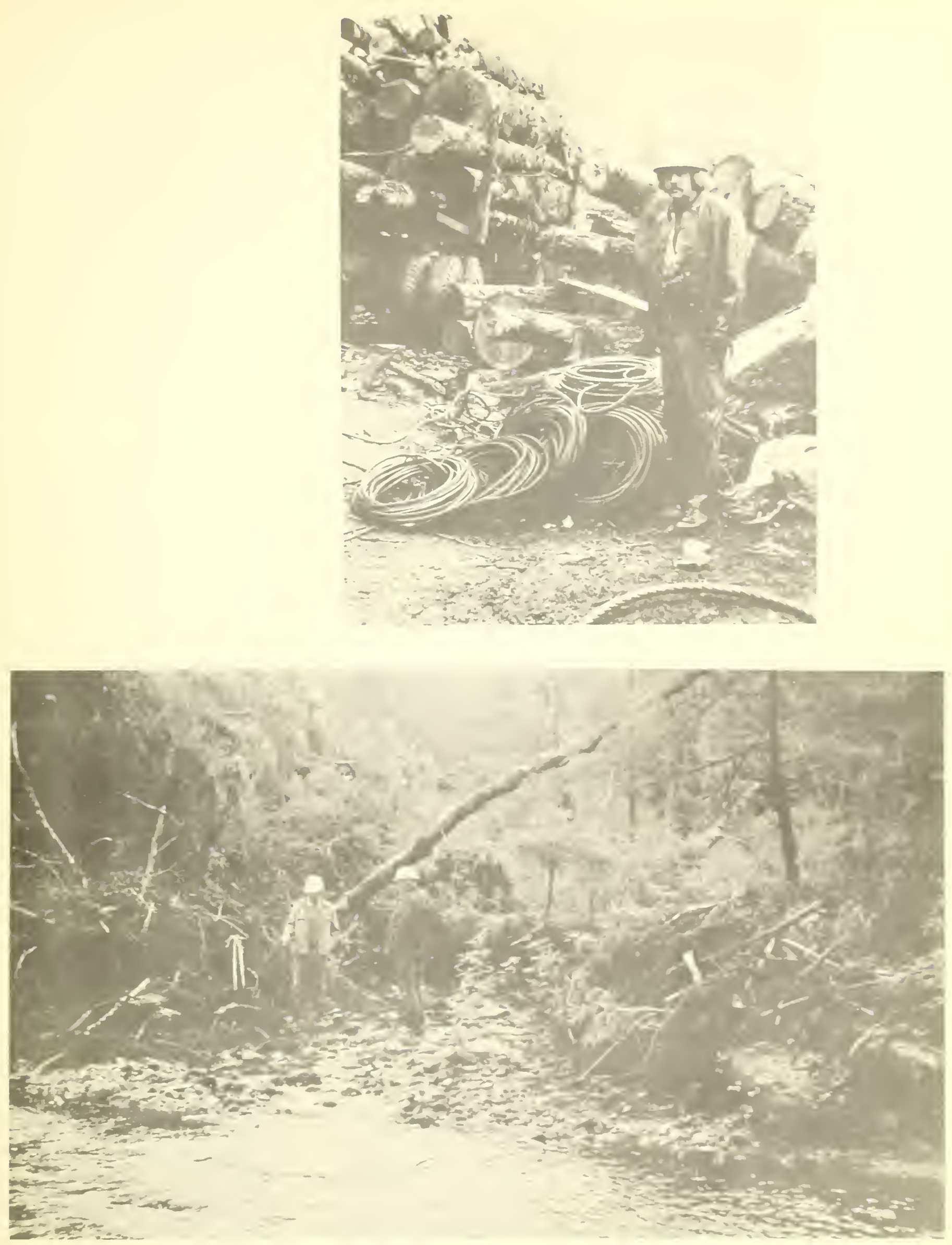


\section{Soils and Water}

The soils and water program is designed to support management activities and land management planning. Soil and water resources are especially critical, because generally any degradation of their quality will adversely affect many other resources.

Soil scientists and hydrologists are actively involved in nearly every interdisciplinary team effort affecting land use planning and project activities Typical projects include timber sale layouts, road locations, stream crossings, culvert and bridge designs, aquaculture facilities, and erosion control measures.

Watershed specialists have developed management guidelines to protect soil and water resources during timber harvesting The guidelines concentrate on preventing erosion and sedimentation. They are used as aids in achieving compliance with State water quality standards.

In 1975, the Forest Service started a three-part water quality monitoring program. Long-term "base" stations were established on selected watersheds that are not intended for management activities for at least 15 years. Data produced from this part will help in evaluation of natural changes. "Project" stations were established on selected watersheds that are proposed for timber harvesting within 3 years. Data from this part will help in evaluation of whole watersheds and parts of watersheds. "Activity" stations were created for highfrequency, low-duration monitoring of selected management activities, such as bridge and culvert installations. All three parts of the monitoring program will help determine the effectiveness of "best management practices" used to comply with State water quality standards.

Many field soil scientists and hydrologists conduct soil and water resource inventories. These are conducted concurrent with management plans, and the information is used for improving management activities.

\section{Land Uses}

Land occupancy involves the appropriation, designation, classification, and use of national forest land for public or private purposes. Included are public recreational areas, resorts, recreational residences, winter sports sites, and other related uses which are considered part of the recreational resource. Other land occupancies involve many public and private nonrecreational uses, such as power developments, roads, airfields, residences, and industrial sites. These occupancies are generally authorized through one of a variety of special use permits, easements, or licenses issued to private, local, or State agencies and through memoranda of understanding or permits to other Federal agencies.

Future land occupancy demands are expected to exceed those of the past. These demands will be greatest along the expanding transportation system and, in some cases, will conflict with demands for other resource uses.

Land occupancies under special use permits involve several public and private uses. Private and semiprivate recreational uses consist mainly of summer homes and organizational camps. Examples of public uses, other than for recreation, are communication sites, dams, powerlines, and gravel pits. Many private nonrecreational uses are for year-round residences and for storage facilities. Most summer homes are located in groups, but a few isolated ones still exist. Year-round residence permits were issued in the past to assist in development of communities where no private land existed for such purposes. With land selection opportunities now afforded the State under the Statehood Act, the need no longer exists for future expansion of the year-round residence program. And, new permits are no longer being issued.

Homesteading of national forest lands suitable for agriculture was formerly permitted under the Forest Homestead Act of June 11, 1906. Lands with agriculture potential were occupied and patented early in the days of the law's existence. Because of a lack of additional suitable land, the 1906 law was repealed on October 23, 1962. Consequently, there is now no authorization for homesteading on national forest land
Before the Alaska Statehood Act, where a need existed near communities or settlements, the Forest Service could issue homesite permits. At that time, homesite permittees could acquire fee title to the lot. Under the Alaska Statehood Act, Alaska was authorized to select as much as 400,000 acres from national forest lands for community expansion and recreation. Now, the need for homesites is expected to be met from the lands selected by the State of Alaska and distributed to the public. State selections are to be completed by 1984 State land selections have many of the same management implications for national forest lands as do the Native selections under the Alaska Native Claims Settlement Act.

For many reasons, including the so-called land freeze and passage of the Alaska Native Claims Settlement Act, progress toward completing the State land selection program has been relatively slow to date. The State, as well as the Forest Service, is now giving it high priority. The State, as well as the Forest Service, has asked communities eligible to select lands from the national forests to identify their development and expansion land needs. The State Commissioner of Natural Resources and Regional Forester have met to identify and resolve conflicting interpretations of the act and to remove historical barriers in the selection and grant process

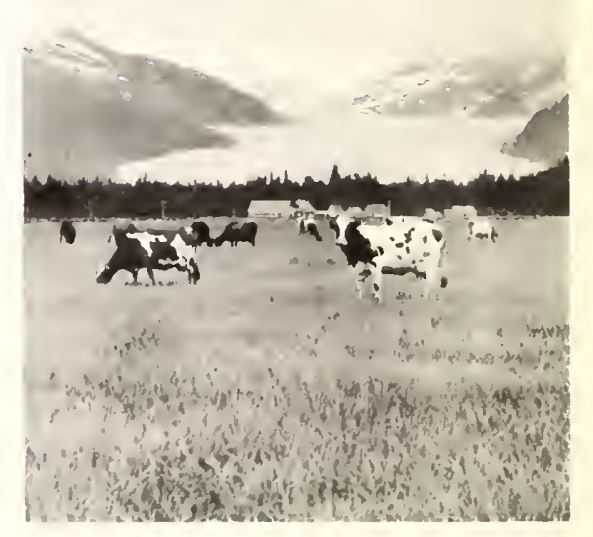

Dairy cattle grazing in the shadow of Mendenhall Clacier near Juneau, Alaska, in the twenties. 


\section{Minerals}

Prospecting and mining played a major role in the settlement and development of Alaska. After the discovery of largelode gold deposits at luneau and Douglas in 1882, prospecting activity increased. Copper was discovered in the Kasaan and Mt. Jumbo areas of Prince of Wales Island. A high-grade gold mine was started on Chichagof Island. Gypsum was found at Iyoukeen Cove on Chichagof Island; large iron deposits at Snettisham. Union Bay, and Klukwan; and immense deposits of limestone on islands west of Prince of Wales Island. The discovery of copper and other minerals also contributed to the development of southcentral Alaska.

The only mine operating at present in southeast Alaska is a barite mine in Duncan Canal just west of Petersburg. Present prospecting indicates that a large deposit of nickel-copper ore is on Yakobi Island as well as an extremely large deposit of molybdenite ore on the mainland east of Ketchikan. Smaller deposits of these minerals as well as uranium, nickel, tungsten, lead and zinc are known to exist elsewhere in the region. Additionally, large areas of the Chugach and Tongass National Forests have potential for petroleum and gas production.

All national forest lands, unless withdrawn, are subject to entry and mining under the General Mining Law of 1872 , as amended Secretary of Agriculture regulations protecting surface values during mining activities on national forest lands are also administered by the Forest Service.

Japan and the west coast of the United States appear to be the logical volume markets for Alask an ores and concentrates. The ability of Alaskan minerals to compete in these markets is affected by high costs of mining operations, particularly high labor costs.

Development of the mineral resources of the region will have an increasingly important effect on the economy of communities within the national forests as well as on other resources. Many secondary effects that are social and economic in nature will affect national forest management. Offshore oil development cannot be accomplished without onshore support facilities which may need to be built on national forest lands.
The Forest Service recognızes the importance of oil, gas, and mineral resource development to the well-being of Alaska and the Nation It also taces the challenge of intergrating this development into the management and protection of all other resource values occurring on national forest lands in Alaska.

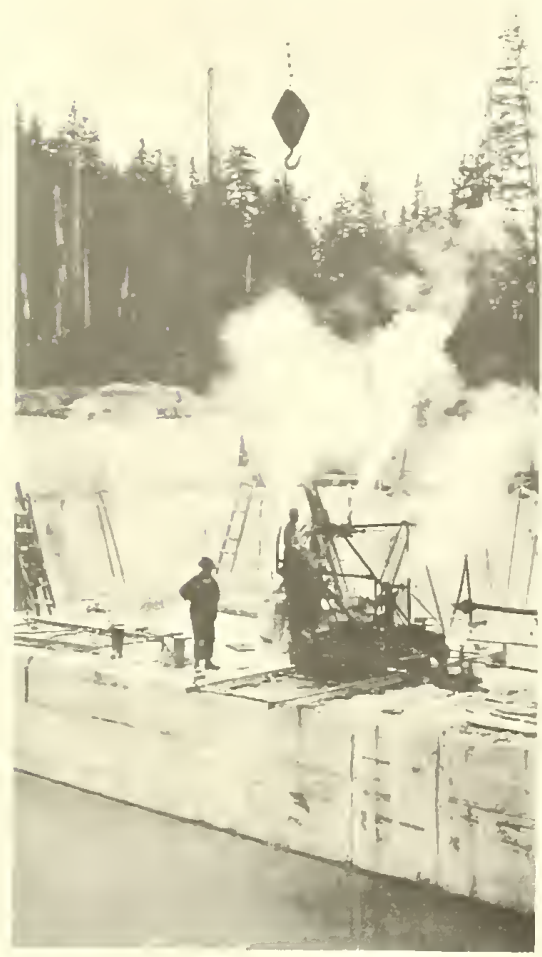

Marble quarry.

Tokeen, Marble Island, 1924

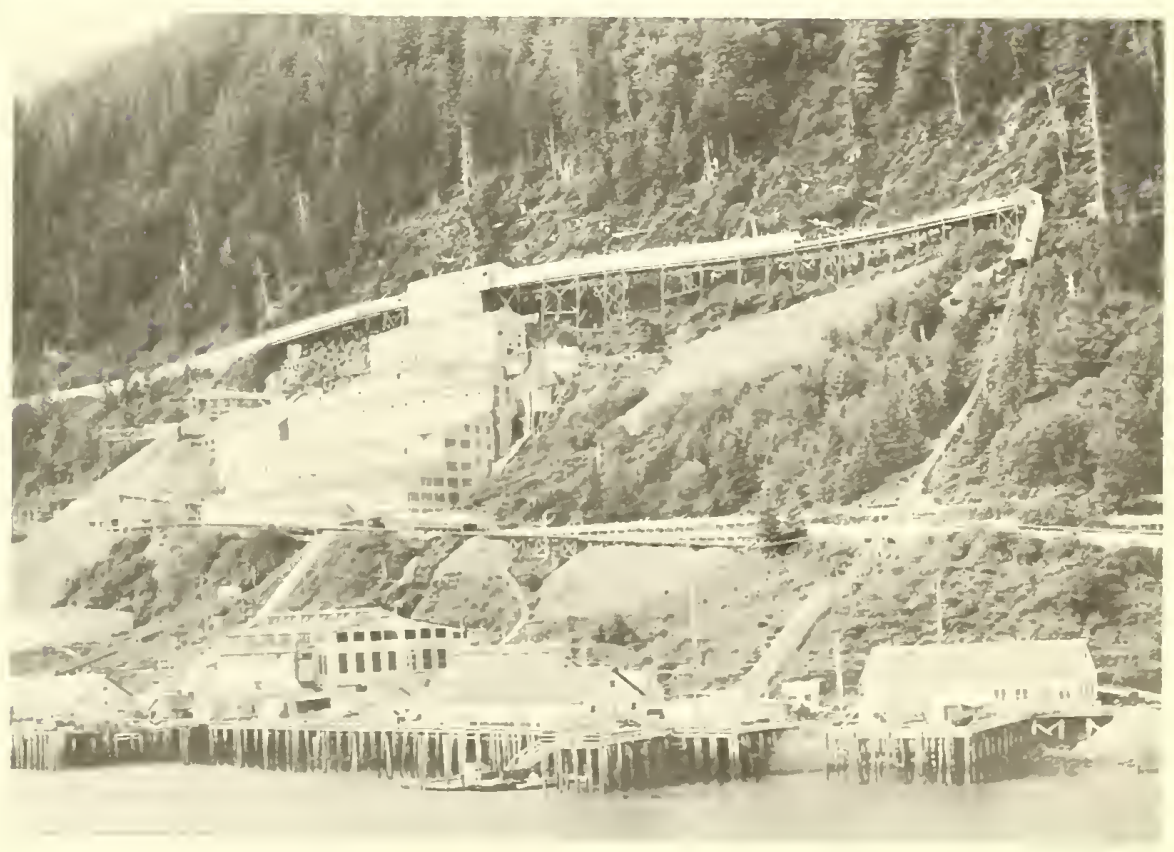

Alaska-Juneau Gold Mining Company of Juneau, Alaska, in the thirties. 


\section{Transportation System}

The Forest Service plans, designs, and constructs transportation systems to support various resource activities and provide access for management, use, and protection of national forest lands. The State of Alaska has primary responsibility for planning, project development, design, and construction of regional highways and air facilities, as delegated by the Federal Highway Administration and the Federal Aviation Administration

The main purpose of State highway systems is to provide for the movement of people and materials from one community to another, regardless of land and resource allocations along the way. The Forest Service also directs its efforts toward the development of resourcerelated transportation systems. Proposals for developing other major arterial highway systems may come from other sources.

Long-term transportation planning involves consecutive developments that improve a transportation system over time. The system must include a cost- effective combination of available transportation modes. Costs to be weighed include those that are social or environmental in nature as well as those that are traditionally economic. Longterm planning must be sufficiently flexible to accommodate changing community needs, changing trends in land uses and values, and rapid evolution in the technological state of the art.

The Forest Service maintains about 1,730 miles of a road system in Alaska. During each calendar year, about 200 miles of system roads and 50 miles of temporary roads are built for timber access in the Tongass National Forest. Most of the mileage will be constructed by timber purchasers as part of their operations. These system facility costs will be allowed through purchaser credits. Construction of about 12 miles of timber access roads and several permanent bridges are finished through public work contracts every year. All current timber sales include permanent roads as part of contractual agreements. This provides the Forest Service with the needed contractural control to meet environmental and resource requirements.
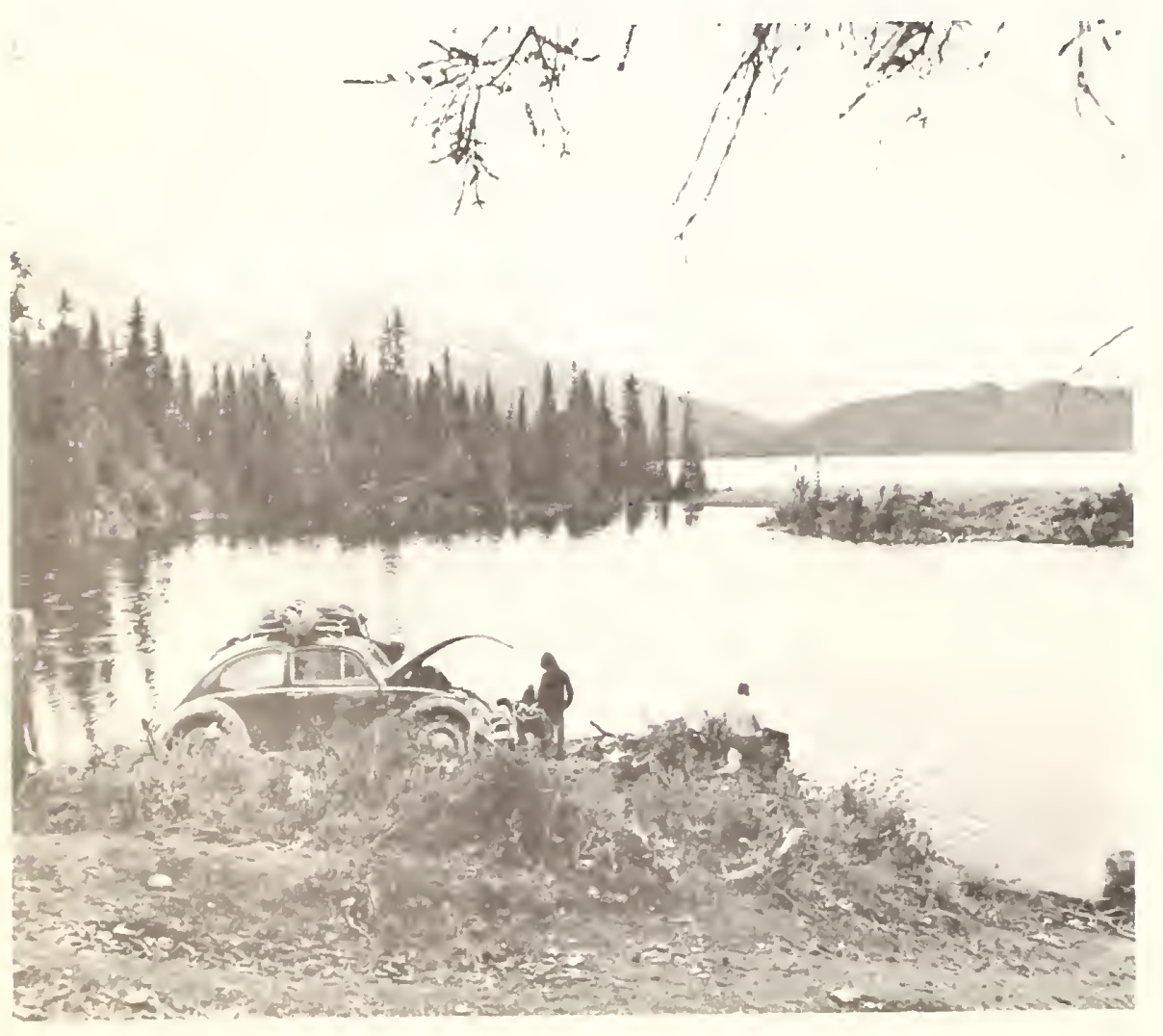

The trail system is receiving added emphasis in the Alaska Region's programs. About 500 miles of trails are maintained throughout the region. Another 20 to 30 miles of trails are built in the Chugach and Tongass National Forests each year. But, the region still has several hundred miles of trails that need reconstruction.

The transportation system includes other facilities, such as terminal sites, airfields, docks, and vessel-mooring structures. Unlike many other national forests, the various resources and publics cannot be adequately served solely by a land-based system. The topography and geography dictate the need for a comprehensive multimodal system.

Resource-oriented activities, such as timber management, habitat improvement, recreation, minerals exploration and developments, commercial fish harvesting and processing, and game and fish management, all require some sort of access. Management of timber resources

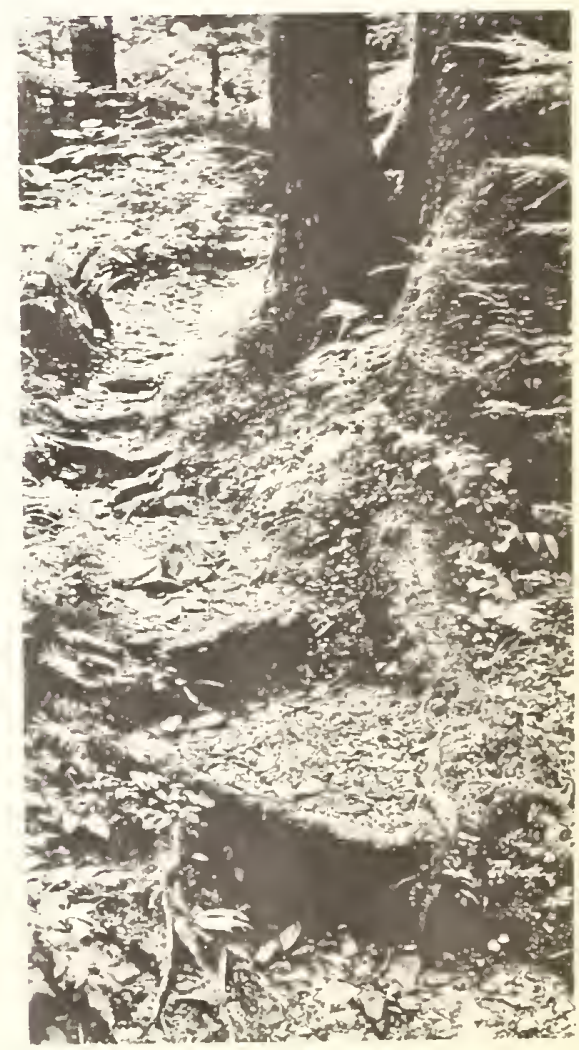


may require several modes of transportation that result in extensive road networks, different log yarding systems, and a determination of which water transportation method will be most compatible with all resources.

Roads now serve most of the developed recreational campgrounds and picnic areas. Visitors to remote recreational cabins gain entry mainly by floatplanes, although some cabins are accessible by boats. The protected waterways and thousands of miles of shoreline also provide small boat access to Jiterally millions of dispersed recreational opportunities. Hiking trails are most in demand near communities, although the need for trail maintenance greatly reduces their use. In some cutover areas, old logging roads may provide access to certain types of recreational activities. But, in most cases, the difficulties associated with getting vehicles to such remote road networks restrict road use to foot traffic and occasionally a trail bike.

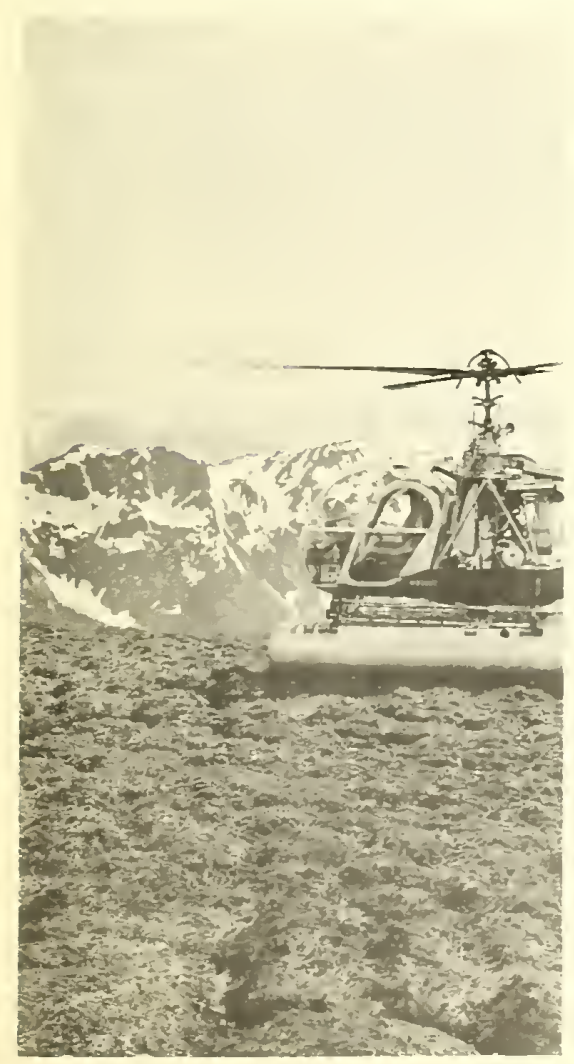

Prospecting and the developing and processing of mineral resources can necessitate development and use of various methods of transportation, including aerial trams. Currently, the development and removal of minerals is not a major activity. Recent exploratory work, however, indicates transportation facilities associated with mineral developments can be expected to increase.

Transportation systems must be planned in conjunction with overall land manage ment plans to fit all resource objectives. Land-based segments of the system are generally constructed in connection with project plans, such as individual timber sales. Their effects on other resources, economics, and future maintenance needs are considered during planning phases.

Marine corridors are well defined in Alaska. They follow fiords, straits, and passages that intersect the rugged mountains of the mainland and the large islands of the region. The scarcity of natural land transportation corridors make such corridors a valuable resource in themselves.
The Forest Service cooperates with the U.S. Department of Energy's Alaska Power Administration and the U.S. Army's Corps of Engineers to develop plans for hydroelectric projects.

Regional corridors may be identified and used for transportation, power transmission, and communication purposes. With few exceptions, power is locally produced, and communication is by microwave transmission.

In addition to the road, air, and port facilities directly concerned with the management of forest resources, the Forest Service has a responsibility to actively participate in the planning, project development, design, and construction of regional highways and air and port facilities to be constructed on land managed by the Forest Service. These facilities, although not primarily dedicated to land management, will serve this function to a large degree. Their effects on other resources, economics, and future maintenance must be given full consideration.

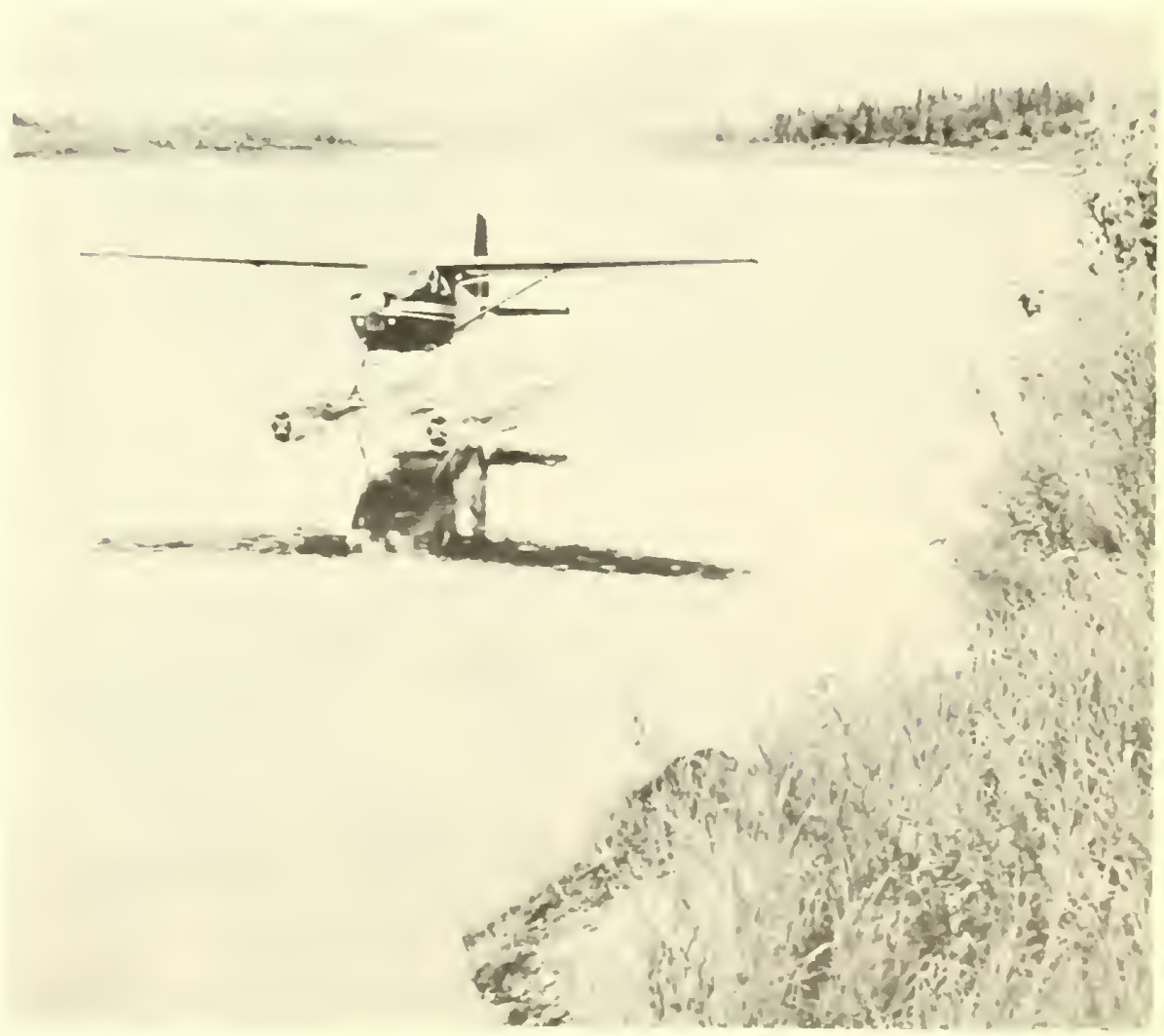


Human Resource Programs

\section{Youth Conservation Corps}

The Youth Conservation Corps (YCC) program began in 1970 with a pilot program on the Chugach National Forest That year, 48 young men and women participated in the program. Now, about 150 Alaskan youths participate each year. They live at camps in Craig, Hydaburg, Juneau, Kake, Kenai Lake, Ketchikan, Klawork, Petersburg, and Sitka (table 3).

The YCC program gives young people an opportunity to gain an appreciation for our natural resources by accomplishing conservation-related work projects in the national forests and by receiving environmental awareness training. YCC is an 8-week summer program designed to-

- Accomplish meaningful conservation work on public lands

- Provide employment opportunities for young people who are 15 to 18 years of age and from all social, economic, ethnic, and racial backgrounds.

- Help YCC participants develop an awareness and appreciation for the Nation's natural environment and heritage

New YCC work projects are planned each year. Some of these include improving wildlife and fisheries habitats, constructing trail bridges, and maintaining recreation cabins, trails, campgrounds, and picnic areas.

\section{Young Adult Conservation Corps}

Young Adult Conservation Corps (YACC) was started nationwide in 1977. In Alaska, about 400 young people rind jobs through the State's Job Service Centers each year and are employed by the Forest Service under the YACC program (table 3).

The program provides year-round jobs for unemployed men and women who are 16 to 23 years of age and from all social, ethnic, and racial backgrounds. They pertorm useful conservation work and other services on Federal and non-Federal public lands and water areas. 
Participants receive training for the basic skills they will need for later permanent employment. Although mainly an employment program, its other goals are to incorporate meaningful sociability training and environmental awareness activities as part of the work.

\section{Other Human Resource Programs}

In addition to YCC and YACC, the Forest Service provides training and work opportunities in these programs:

Vocational rehabilitation programMeaningful work experiences and vocational training are provided in nonpaid positions for handicapped persons. The Forest Service has the authority to employ severely handicapped persons, and they are actively recruited.

Cooperative education - This program provides for periods of study-related employment in suitable types of work for students in 2- or 4 year colleges who are pursuing certain degree curricula.

RSVP-The Rural Student Vocational Program sponsored by the State of Alaska offers secondary school students brief "details" with employers. The Forest Service is a participating agency.

Summer aid program - Summer employment is offered to needy youths to provide meaningful work experiences for individuals $16-22$ years of age who might not otherwise have the opportunity to obtain a summer job.

Volunteers program - Volunteer services help with Forest Service programs or activities which would not be accomplished by the normal work force.

Stay-in-school program-This program is similar to the Summer Aid Program, except that work is offered throughout the year for students, ages 16-22, who need temporary employment to continue their education.

Summer employment program-Work is provided during the summer for students, ages 18 or older, attending college or needing work opportunities.
Table 3-Conservation Corps information, 1979

\begin{tabular}{lcl}
\hline Camp location & $\begin{array}{c}\text { Number of } \\
\text { enrollees }\end{array}$ & Type' \\
\hline YCC: & 8 & Nonresidential \\
Craig & 38 & 7 -day residential \\
Eagle River (Juneau) & 5 & Nonresidential \\
Hydaburg & 6 & Nonresidential \\
Kake & 48 & 7 -day residential \\
Kenai Lake & 8 & Nonresidential \\
Ketchikan & 10 & Nonresidential \\
Petersburg & 15 & 5-day residential \\
Revillagigido (Ketchikan) & 15 & Nonresidential \\
Sitka & & Residential \\
YACC: & 110 & Nonresidential \\
Chugach National Forest & 45 & Residential \\
Tongass National Forest & & Nonresidential \\
Chatham Area & 35 & Residential \\
Ketchikan Area & 30 & Nonresidential \\
Stikine & 40 & Residential \\
\hline
\end{tabular}

'In a residential camp, enrollees live at the camp for either 5 or 7 days each week. In nonresidential camps, enrollees live at home and commute to work 5 days a week.

CETA Title VI-This public service employment program provides year-round jobs under the Comprehensive Employment Training Act (CETA) for people who meet certain unemployment and lowincome criteria. The Forest Service is the "host" agency for about 50 people who work under the CETA program.

\section{Equal Opportunity}

U.S. Department of Agriculture policy does not permit discrimination because of race, color, national origin, sex, religion, handicap, or any other nonmerit factor.

Any person who believes he or she has been discriminated against in any USDArelated activity should write to the Secretary of Agriculture, Washington, D.C. 20250 

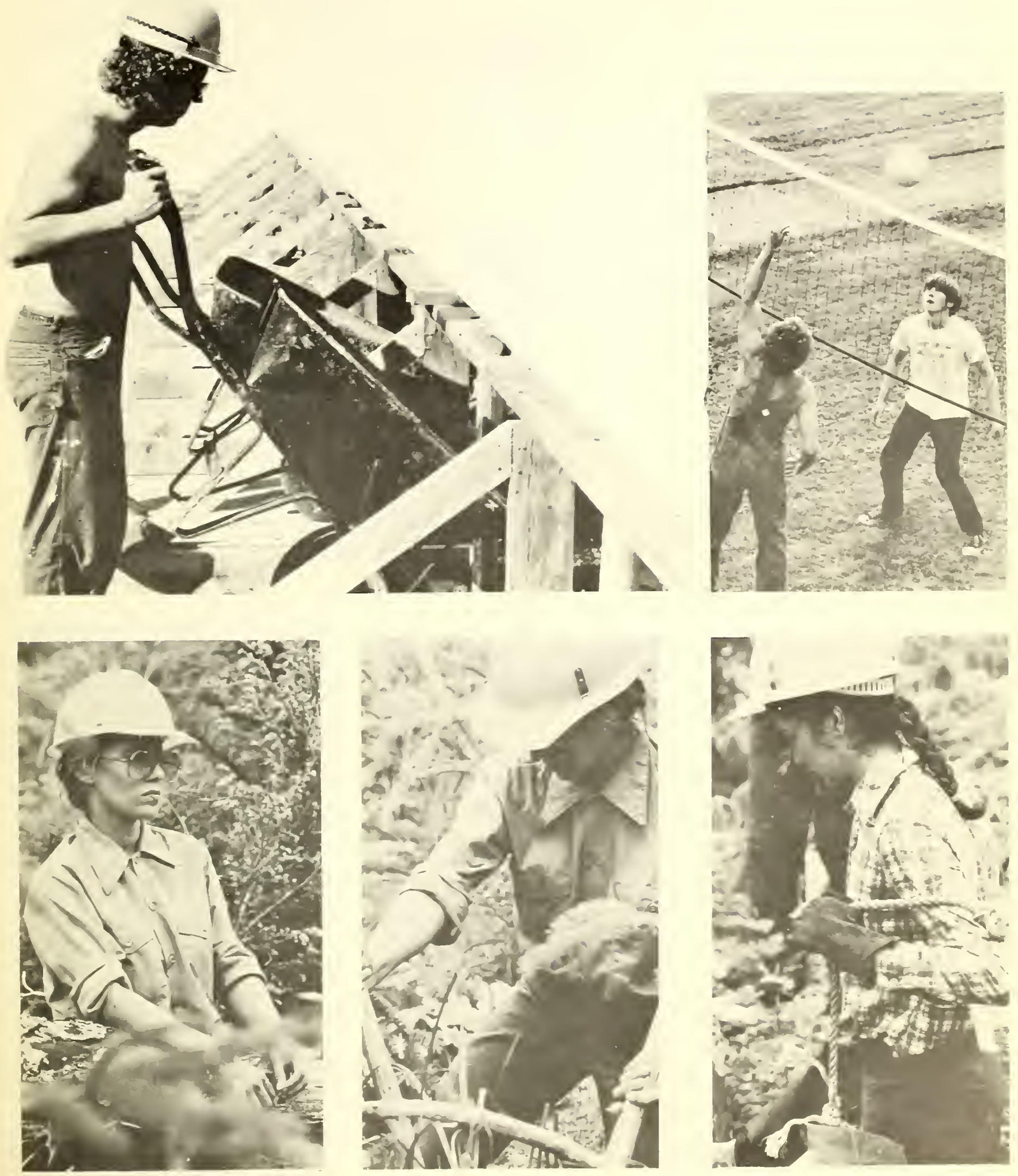


\section{Environmental Education}

Environmental and resource management issues have always been complex. But, today's political, economic, and social factors influencing those issues greatly increase their complexity. The Forest Service environmental education program is geared toward helping people identify, understand, and support wise resource management. Participants in the program-

- Identify environmental problems and relationships.

- Collect and interpret data about those environmental problems and relationships.

- Develop alternative solutions to environmental problems

- Predict the environmental and societal consequences of those alternative solutions.

- Develop action plans to implement selected alternatives.

The program includes workshops for teachers and resource managers; development of environmental teachings aids, activities, and media presentations; assistance with school districts' curriculum development; and design of environmental study areas.

\section{Information Services}

Information of use to the general public is of ten developed during many Forest Service activities. Added emphasis has been given to "technology transfer" programs that attempt to transfer information from Covernment, industry, and other groups to potential users in the public sector. "Technology transfer" programs are especially tailored for private landowners who may need information about improving their forestry management.

Publications are used to help disseminate information about such topics as fire prevention, recreational facilities, personnel recruitment, land management plans, and forest resources. Publications, research reports, and some working papers produced by the Alaska Region are generally available for free. Contact the USDA Forest Service(OI), P.O. Box 1628, luneau, Alaska 99802. Copies are also distributed to regional libraries in Alaska. Most Forest Service
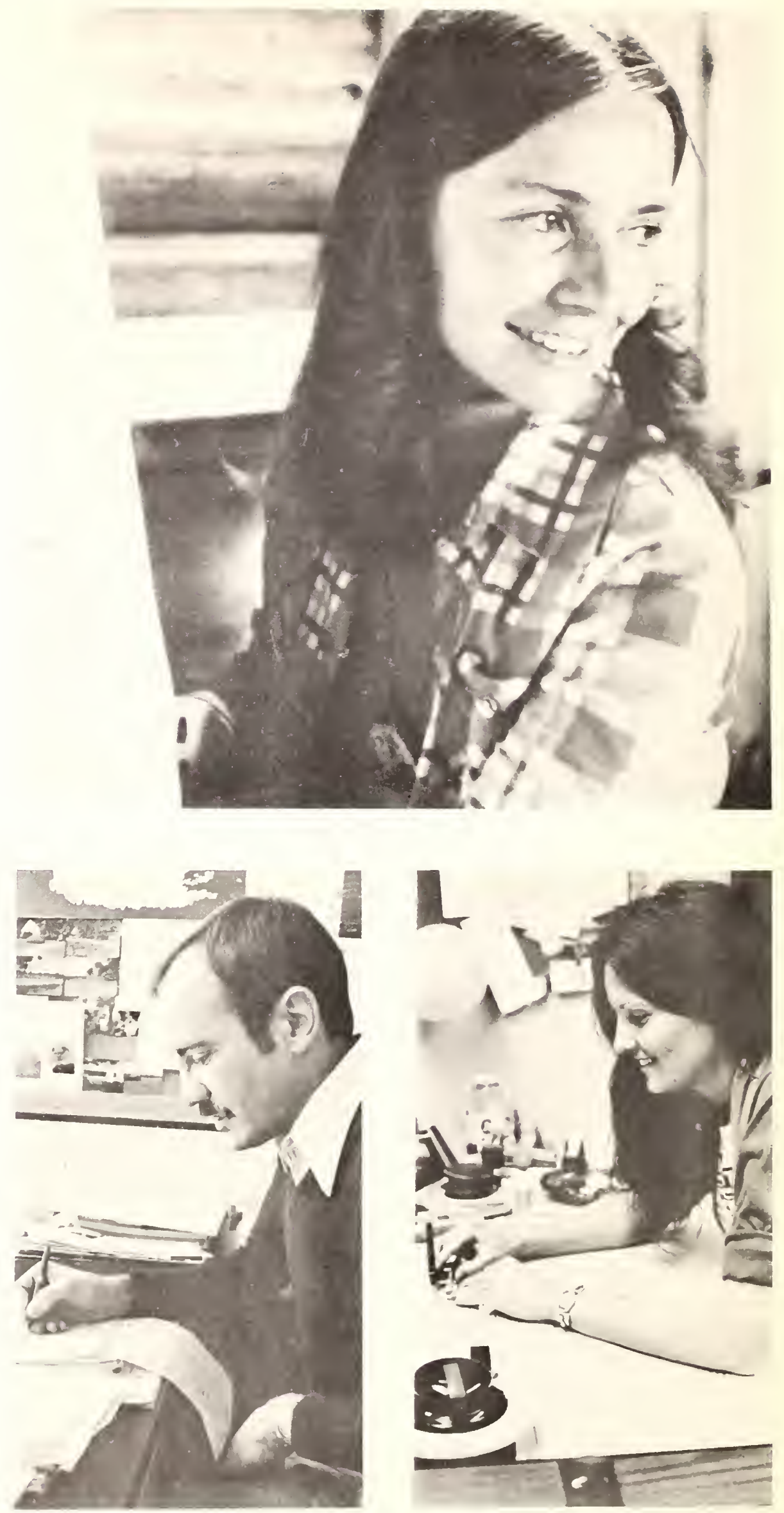
and other U.S. Department of Agriculture publications may be secured through local libraries by arranging an interlibrary loan from the National Agricultural Library (USDASEA-TIS), Beltsville, Maryland 20705.

Public involvement is often needed to resolve important issues affecting the Nation's national forests. In Alaska, extensive public involvement in the Forest Service decisionmaking process was solicited during development of the "Tongass Land Management Plan." Similar public involvement efforts are being made for the Chugach land management plan.

Staff specialists provide liaison services to legislators and other public officials, representatives of printed and electronic media, foreign visitors, free lance writers, and others who may be interested in Forest Service activities. Liaison services are coordinated by the Regional Forester and the Director of the Office of Information

\section{Administrative Support}

Expanding populations in Alaska and increasing activity in the various resource programs have severely taxed the region's existing support facilities, such as the radio communications system, family housing, crew housing, and warehouses, Work is underway to relieve the strains on these facilities

The Alaska Region has the most complex radio system in the Forest Service.

Because of limited commercial telephone service, often the only communications from many remote work centers come by the region's radio system. A new system was installed in 1974 to provide a direct link between field crews and their headquarters. It has greatly increased the safety of employees and the efficiency of work programs. The Alaska Region's radio system has been designated as the emergency radio system for coastal Alaska from Ketchikan to Kodiak. During and after such natural disasters as earthquakes, the region's radio system provides emergency communications to various disaster headquarters.
Housing Forest Service employees at remote locations has always been a difficult problem. With rapidly expanding work programs, an even more critical shortage of adequate housing has developed. In many areas, the ability to recruit and retain qualified employees is directly related to the availability of suitable housing. Family units are being constructed to help ease this critical shortage, as well as barracks for field crews.

The rapid increase in population in Alaska has severely affected Forest Service recreational facilities. Federal Water Pollution Control Act amendments and the Safe Drinking Water Act require extensive reconstruction of facilities to bring them into compliance with standards set by law. New improvements, such as water and waste disposal systems, are needed at many campgrounds and at such major attractions as Portage and Mendenhall Glaciers.
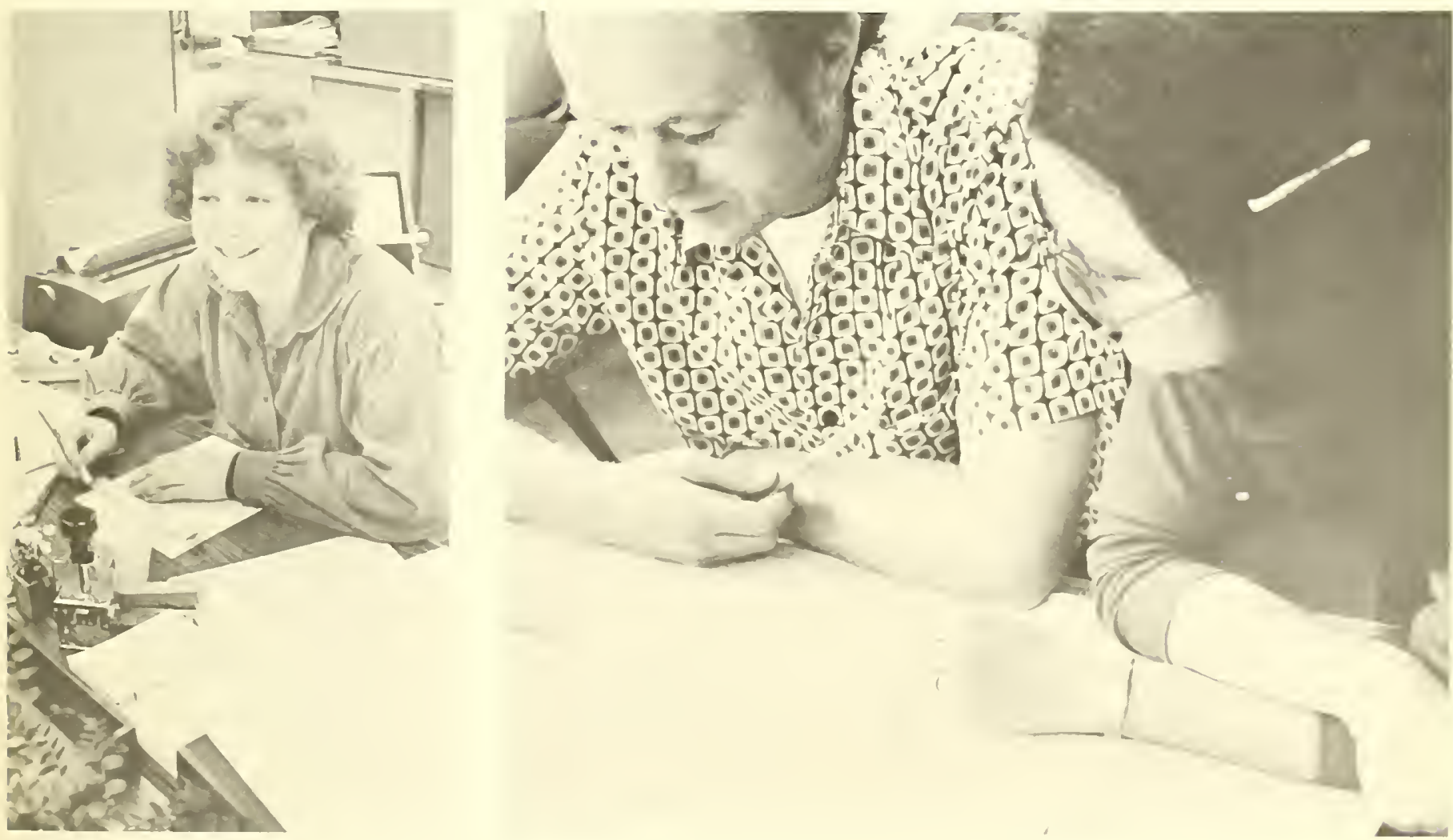


\section{Key Forest Service Personnel}

This section lists the names and titles of key Forest Service personnel in Alaska. Unless otherwise noted, the mailing address is USDA Forest Service, P.O. Box 1628, Juneau, Alaska 99802.

The main telephone information number for Alaska is (907) 586-7416. If calls are initiated within the Federal Telephone System outside Alaska, contact the FTS operator in Seattle at $399-0150$ and ask for the Alaska number.

\section{Line Officers of the Alaska Region}

John A. Sandor, Regional Forester (586-7263).

Michael L. Barton, Deputy Regional Forester (586-7263).

Clay G. Beal, Forest Supervisor, Chugach National Forest, Pouch 6606, Anchorage, Alaska 99502 (279-5541). John F. Butruille, Forest Supervisor, Tongass National Forest, Stikine Area, P.O. Box 309, Petersburg, Alaska 99833 (772-3841).

William P. Gee, Tongass National Forest, Chatham Area, P.O. Box 1980, Sitka, Alaska 99835 (747-6671).

James S. Watson, Forest Supervisor, Tongass National Forest, Ketchikan Area, Federal Building, Ketchikan, Alaska 99901 (225-3101).

\section{Program Leaders of the Pacific Northwest Experiment Station}

Donald C. Schmiege, Forestry Sciences Laboratory, P.O. Box 909, Juneau, Alaska 99802 (586-7301).

C. Theodore Dyrness, Institute of Northern Forestry, Fairbanks, Alaska 99701 (479-7313).

\section{Directors of Alaska Region Staff} Units

Manuel R. Archuleta, Civil Rights and Human Resources (586-7275).

Frank C. Arnold, Personnel Management (586-7257).

J.B. Arthur, Management Systems (586-7261).

Robert Birnstengel, Fiscal and Accounting Management (586-7248).

William J. Bradley, Administrative Services (586-7252).

James A. Calvin, Lands, Minierals, and Watershed Management (586-7247).

Ramon F. Clar, Environmental Coordinator (586-7152).

Dale Heigh, Timber Management (586-7271)

William R. Kinworthy, Engineering and Aviation Management (586-7266).

Tom Lennon, Planning, Programing, and Budgeting (586-7484).

Marvin Meier, State and Private Forestry; Pouch 6606, Anchorage, Alaska 99502 (276-0939).

Sigurd Olson, Wildlife and Fisheries Management (586-7529).

Konrad B. Reinke, Office of Information (586-7448).

Richard Wilson, Recreation Management

(586-7259).

\section{Other Offices}

Admiralty Island National Monument, Juneau (789-3111).

Misty Fiords National Monument, Ketchikan (225-3101).

Cordova (424-7661).

Craig (826-3271)

Kodiak (486-3320).

Seward (224-3023).

Wrangell (874-2323).

Yakutat (784-3359). 


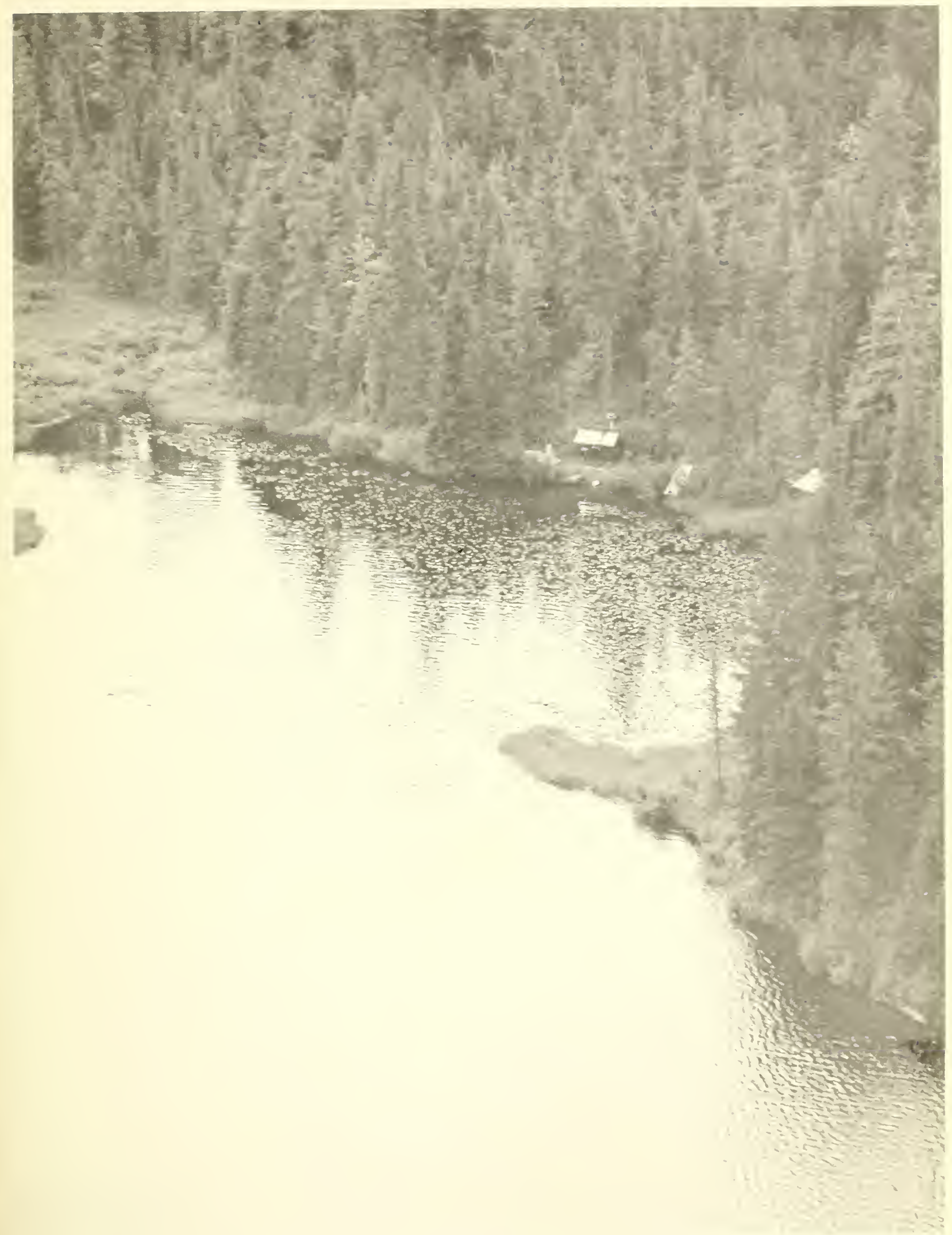


